\title{
Low-temperature thermochronology of the South Atlantic margin along Uruguay and its relation to tectonic events in West Gondwana
}

3

João Pacífico Silveira Luiz Machado ${ }^{1,2} *$, Andréa Ritter Jelinek ${ }^{2}$,
Randell Stephenson ${ }^{1}$, Claudio Gaucher ${ }^{3}$, Marcos Müller Bicca ${ }^{2}$, Leticia
Chiglino $^{3}$, Frederico Antonio Genezini
${ }^{1}$ School of Geosciences, University of Aberdeen, United Kingdom
${ }^{2}$ Instituto de Geociências, Universidade Federal do Rio Grande do Sul, Porto Alegre,
Brazil
${ }^{3}$ Facultad de Ciencias, Universidad de la República, Montevideo, Uruguay
${ }^{4}$ Instituto de Pesquisas Energéticas e Nucleares, Centro do Reator de Pesquisas, São Paulo, Brazil
*Correspondence (j.luizmachado.18@abdn.ac.uk / joao.machado@ufrgs.br)


exhumation of the basement until Early Cretaceous. The onset of this long-term uplift is correlated with orogenesis and terrane accretions in the SW margin of West Gondwana during the Paleozoic. Lithosphere thinning and uplift preceding breakup contributed to the continuous Late Paleozoic to middle Mesozoic exhumation, until the voluminous volcanism of the Paraná-Etendeka Large Igneous Province (c. $133 \mathrm{Ma}$ ). This magmatic event, combined with the thermal influence of the Tristão da Cunha mantle plume and rift spreading, likely raised the basement geotherm during the Late Cretaceous. Models suggest a slight increase in temperatures of the UYS from Late Cretaceous until the Oligocene, when a final cooling to surface temperatures took place. Our findings corroborate a long and complex thermal history for Uruguay, with crustal uplift occurring essentially before West Gondwana breakup.

\section{Keywords}

Thermochronometry; Fission-tracks; (U-Th)/He; West Gondwana; South Atlantic.

\section{Introduction}

The Atlantic passive margin in South America was established after Gondwana breakup in the Jurassic-Cretaceous, during which rifting propagated from southernmost Tierra del Fuego towards the NE, forming the eastern continental margins of Argentina, Uruguay and Brazil. Basement uplift and exhumation syn- and post-rift have been widely reported by low-temperature thermochronometry studies in SE Brazil (e.g. Gallagher et al. 1994, 1995; Gallagher \& Brown 1999; Tello Saenz et al. 2003; Hackspacher et al. 2004; Cogné et al. 2011, 2012; Karl et al. 2013; Krob et al. 2019; Van Ranst et al. 2019), where the high escarpments (up to $2.000 \mathrm{~m}$ ) from the Serra do Mar and Serra da Mantiqueira provide an ideal scenario for this research method. Cooling in the region is often associated with uplift and exhumation, related to the far-field effects of the Andean Orogeny and to structural reactivations in the passive margin during the development of the Atlantic Ocean. On the 
other hand, thermochronometry studies are scarcer towards the south of the Atlantic margin, where a subdued topography and low relief are dominant. Published data suggest that an important limit between pre- and post-rift cooling and exhumation is located in the Florianópolis region, southern Brazil (Fig. 1), where a very complex thermal history has been reported (Jelinek et al. 2003; Karl et al. 2013; Hueck et al. 2018a). Further south of this region, thermochronometry studies have reported mainly pre-rift Paleozoic cooling phases in southernmost Brazil (Borba et al. 2002, 2003; Oliveira et al. 2016; Machado et al. 2019), Uruguay (Kollenz 2015; Hueck et al. 2017; Gomes \& Almeida 2019) and Argentina (Kollenz et al. 2017). These were generally linked to Paleozoic orogenic cycles on the active SW margin of Gondwana and the geodynamics of Gondwana breakup. Approximately $800 \mathrm{~km}$ south of Florianópolis, Uruguay has represented an area of increased interest for thermochronometry studies in recent years, but data are still very limited in the region. The Uruguayan shield (UYS) occupies almost half of the territory of Uruguay (Fig. 1 and 2) and includes exposures of the Archean to Paleoproterozoic Rio de La Plata Craton and of the Neoproterozoic Dom Feliciano Belt, associated with the formation of West Gondwana (Hartmann et al. 2001; Gaucher et al. 2011; Oyhantçabal et al. 2011). Although passive margins and cratons are often considered as characterized by long-term stability, the low-temperature thermochronology studies in Uruguay indicate basement cooling since the early Paleozoic, suggesting a lengthy and complex Phanerozoic thermotectonic history. Available data suggest that the main exhumation event in the region was initiated well before Gondwana breakup (Kollenz 2015; Hueck et al. 2017; Gomes \& Almeida 2019). However, the current thermal histories modeled for the UYS by different authors and based on distinct thermochronometers (Kollenz 2015; Hueck et al. 2017; Gomes \& Almeida 2019) suggest alternative phases of cooling and reheating of the basement, and imply conflicting geodynamic models for the regional tectonic evolution. The complex and 
scattered thermochronometry data in the region represent a restraint to our understanding of the tectonic activity preceding South Atlantic rifting and breakup. basement can improve our models for the Gondwana breakup and tectonic activity in the early stages of rifting, including rift propagation northwards. Moreover, it is necessary to evaluate the somewhat conflicting models for exhumation of the UYS. Therefore, with the objective to enhance our knowledge of the thermal history of the region, in this work we combine the methods used individually in previous thermochronometry studies and generate new thermal models for the Uruguayan basement. We present a new dataset with 19 apatite

84 fission-track ages, 42 apatite and 40 zircon (U-Th)/He single crystal ages, from which we model 19 inverse thermal histories across the UYS. After integration with previously published data, we identify the main cooling/reheating phases of the shield and associate

87 them to the collisional cycles in the SW margin of Gondwana, and to the opening of the South Atlantic. Our results support models of a complex long-lived thermal evolution for the

89 Uruguayan shield, and a thermotectonic history that utilizes the thermochronometry data 90 currently available for the region is suggested. 


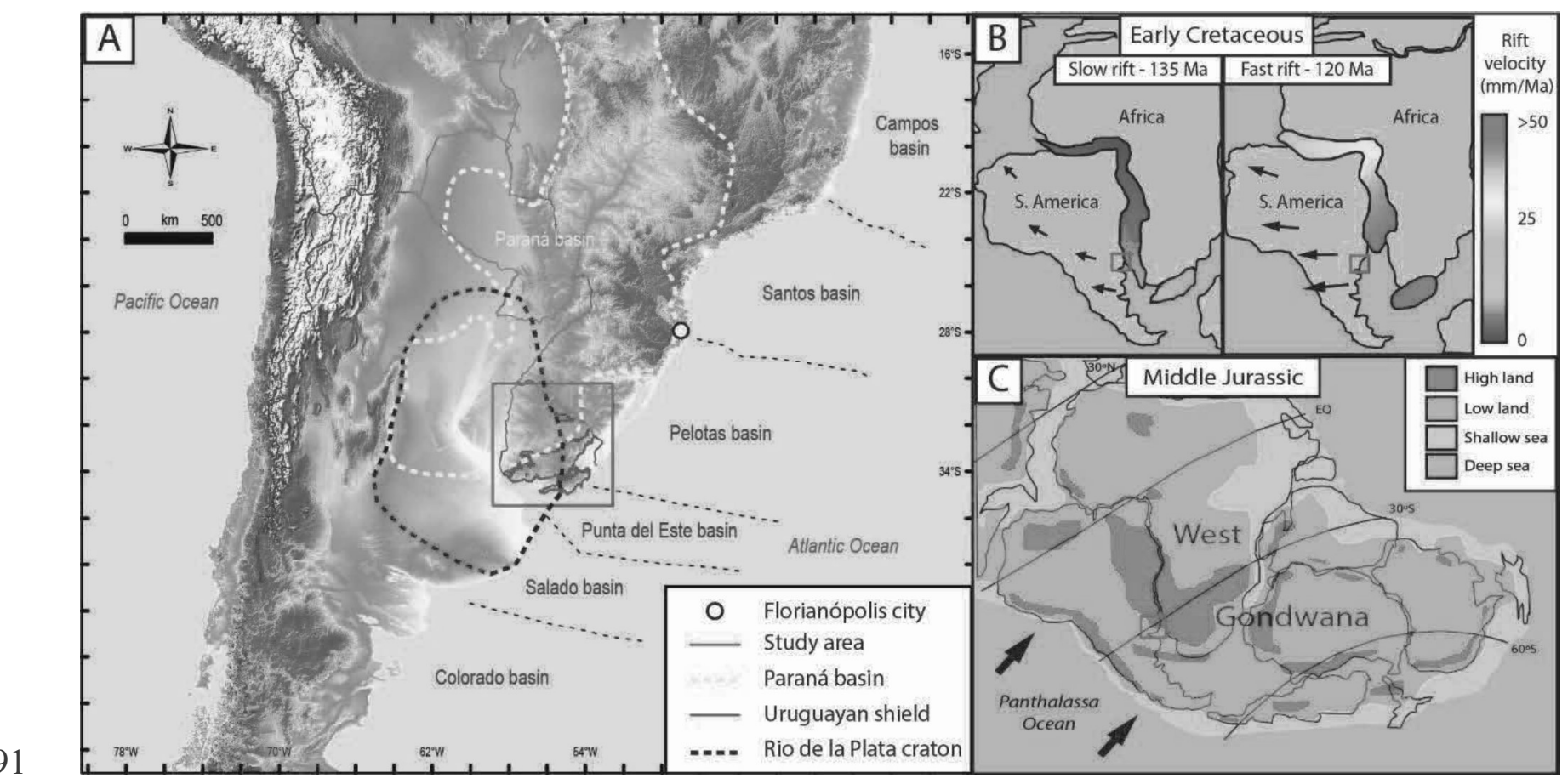

92

Figure 1. Panel with (A) DEM image of the study area in the South Atlantic margin, with schematic boundaries of the Paraná Basin and Rio de La Plata Craton indicated. The region of Florianópolis marks the limit between pre-rift cooling (south) and post-rift cooling (north); (B) study area location during the South Atlantic rift velocity increase (after Brune et al., 2016) and (C) before West Gondwana break-up, with subduction of the Panthalassa Ocean under West Gondwana (after Scotese et al., 1999).

\section{Geological context}

Uruguay is located at the eastern margin of South America and exhibits a surprising geological diversity considering its relatively small size $\left(176.215 \mathrm{~km}^{2}\right)$. Its Precambrian basement records geological events from the Archean, accessible to investigation by exposure across 44\% of its territory (Bossi et al. 1998; Hartmann et al. 2001; Masquelin 2006). The country has low topography and subdued relief, with very few peaks over $500 \mathrm{~m}$ above sea level. The Uruguayan shield crops out mainly in the southern and eastern part of the country, and is divided into four tectonostratigraphic terranes, while the remaining area is covered by Phanerozoic volcano-sedimentary deposits (Fig. 2).

\subsection{The Uruguayan shield (UYS)}

The four UYS terranes are limited by regional shear zones and known, from $\mathrm{W}$ to $\mathrm{E}$, as the: 1) Piedra Alta Terrane (PAT), 2) Tandilia Terrane (TT), 3) Nico Pérez Terrane (NPT), 
109 and 4) Cuchilla Dionisio Terrane (CDT) (Bossi et al. 1998; Bossi \& Gaucher 2004, 2014a;

110 Bossi \& Cingolani 2009). Although this division is still a matter of debate, the westernmost

111 PAT and TT are unanimously considered part of the Rio de la Plata Craton, a major tectonic

112 feature in South America; the easternmost CDT represents the Dom Feliciano Belt and had

113 been associated with the Kalahari Craton, of southern Africa; and the central and highly

114 complex NPT has been considered part of the Rio de La Plata Craton or not, depending on

115 author (see Basei et al., 2005; Bossi and Gaucher, 2004; Gaucher et al., 2011; Hartmann et

116 al., 2001; Masquelin, 2006; Oriolo et al., 2016a; Oyhantçabal et al., 2018; Philipp et al.,

117 2016; Rapela et al., 2011; Santos et al., 2017). In any case, there is consensus that all terranes

118 were finally assembled during the end of the Brasiliano/Pan-African Orogeny

119 (Neoproterozoic), a multi-episodic collision between the Rio de la Plata, Congo and Kalahari

120 cratons and several microcontinents and arc terranes (e.g. Arachania), which culminated with

121 the consolidation of West Gondwana (Gaucher et al. 2009, 2011; Hueck et al. 2018b; Philipp

122 et al. 2018; Schmitt et al. 2018a).

123 


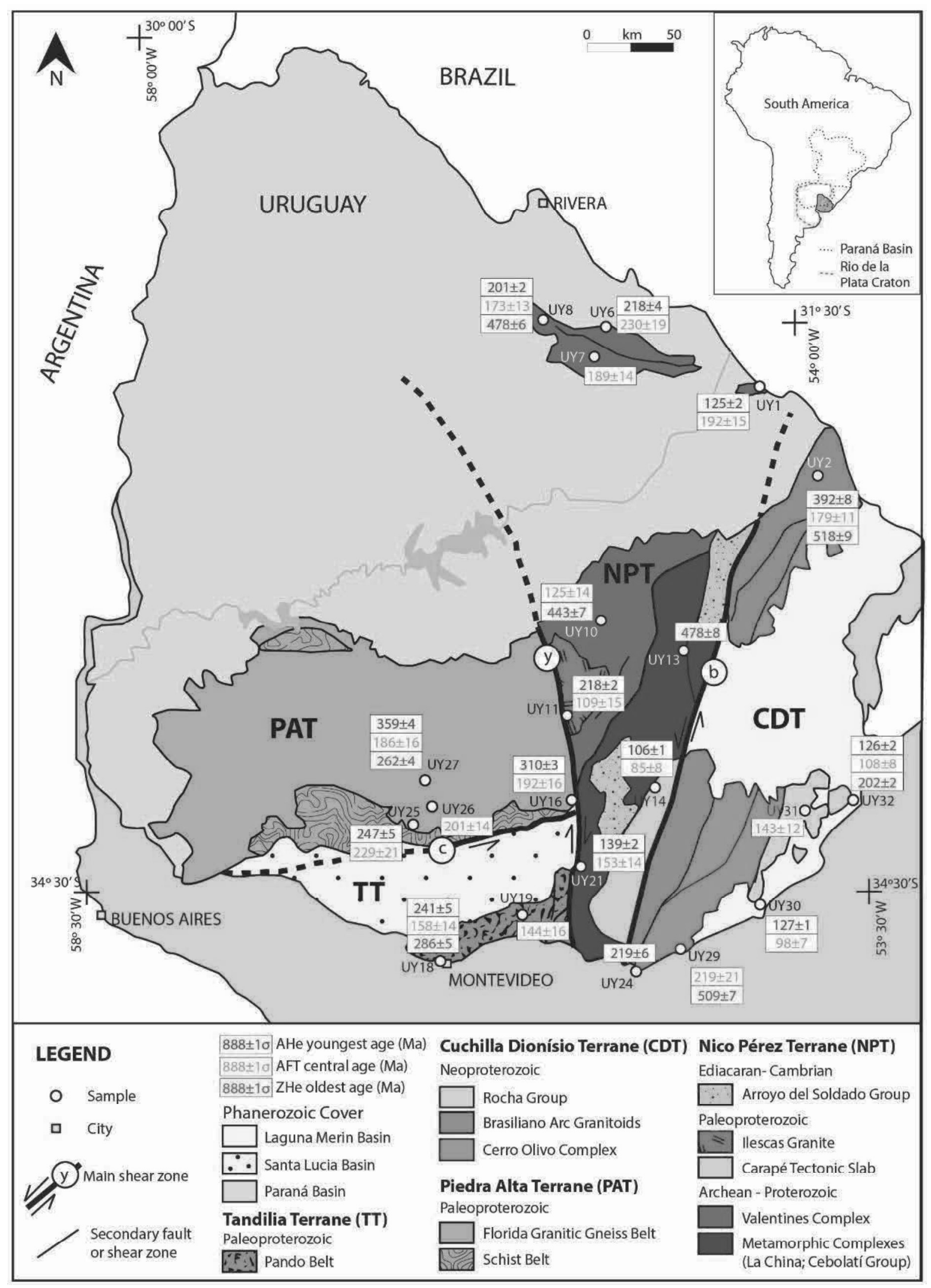

Figure 2. Simplified geological map of Uruguay with sample locations and new thermochronometry ages. Central AFT ages, oldest ZHe and youngest AHe single crystal ages are reported. Main shear zones: (c) Colonia, (y) Sarandí del Yí and (b) Sierra Ballena. Inset map indicates the approximated extension of the

128 Paraná Basin and Rio de la Plata Craton. 

several NE-trending smaller lineaments occur in the NPT and CDT. The oldest lineament is

131 the Colonia Shear Zone, which separates the PAT from the TT (Bossi and Cingolani, 2009).

132 It comprises an E-W trending, several km-thick ultramylonite band showing abundant

133 sinistral shear indicators (Ribot et al., 2005; Abre et al., 2014). The age of the shear zone has

134 been determined by K-Ar ages of deformed granitoids as $1.75 \mathrm{Ga}$ (Faraone, 2018). Central in 135 the shield, the Sarandí del Yí Shear Zone is a mylonitic belt with c. $2 \mathrm{~km}$ width and a NNW136 SSE strike, which displays dextral shearing with sinistral reactivation and limits the western 137 PAT and TT from the central NPT (Bossi \& Gaucher 2014a; Oriolo et al. 2018). Ar-Ar ages 138 of mafic dikes deformed by the main dextral shear yielded Mesoproterozoic ages of c. 1,200 139 Ma (Teixeira et al., 1999), that were related to the tangential collision between the TPA and 140 TT with the NPT during the formation of the Rodinia supercontinent (Bossi \& Cingolani 141 2009; Gaucher et al. 2011; Bossi \& Gaucher 2014a). More recent publications have 142 supported a Neoproterozoic onset of deformation (c. $630 \mathrm{Ma})$, linked to the collision of the

143 Rio de la Plata and Congo cratons during West Gondwana formation (Rapela et al. 2011;

144 Oriolo et al. 2016b, 2018), but the new ages do not rule out a Mesoproterozoic main event 145 (Santos et al., 2017). This discussion is still ongoing and has important implications for the 146 Precambrian evolution of Uruguay. Another major lineament is the Sierra Ballena Shear 147 Zone, a c. $4 \mathrm{~km}$-wide mylonitic belt with NNE-SSW direction that propagates to

148 southernmost Brazil as the Dorsal do Canguçu Shear Zone (Fernandes et al. 1993; Fernandes 149 \& Koester 1999; Oriolo et al. 2018). In Uruguay this shear zone represents the suture 150 between the central NPT and the coastal CDT, and displays sinistral shearing during the end 151 of the Brasiliano/Pan-African Orogeny (latest Ediacaran-Cambrian) with brittle reactivation 152 during the Mesozoic (Bossi \& Gaucher 2004, 2014a; Hueck et al. 2017; Oriolo et al. 2018). 

low-grade metamorphic belts (Arroyo Grande and San José belts), separated by the wide central Florida Belt, which comprises granitoids and gneiss (Hartmann et al. 2001;

Oyhantçabal et al. 2011; Bossi \& Piñeyro 2014). The southern San José Belt is cut by the E-

157 W Colonia Shear Zone and partially covered by the Santa Lucía Basin. The central Florida

158 Belt was intruded by thousands of mafic dikes with E-W direction around 1.79 Ga (Teixeira et al., 1999) which underwent a NW-SE flexure near the Sarandí del Yí Shear Zone, indicating dextral movement during the collision of the PAT and the NPT (Bossi and

161 Campal, 1992; Hartmann et al. 2001; Gaucher et al. 2011; Bossi \& Piñeyro 2014; Oriolo et 162 al. 2016b; Oyhantçabal et al. 2018). The PAT yielded widespread positive $\varepsilon N d$ values and $\mathrm{Nd}$ model ages between 2.4 and $2.1 \mathrm{Ga}$, which shows its juvenile character and lack of an Archean basement (Pamoukaghlián et al., 2017).

166 Montevideo Formation (Pando Belt) and several intrusive granitoids, such as the Soca

167 rapakivi granite (2056 Ma: Santos et al., 2003) and the La Tuna Granite, which yielded a U$168 \mathrm{~Pb}$ crystallization age of $2156 \mathrm{Ma}$ (Pamoukaghlián et al., 2017). The terrane continues to the 169 south beneath the Río de la Plata and into Argentina, cropping out again in its type area 170 (Tandilia) in the southern Buenos Aires Province, Argentina (Bossi and Cingolani, 2009). 171 Apart from older ages for the metasediments and intrusive granitoids compared to the PAT,

172 Nd model ages are in average 200 Myr older in the TT (Pamoukaghlián et al., 2017),

173 matching comparable model ages in the type area in Argentina (Hartmann et al., 2002).

174 Furthermore, Neoproterozoic anorogenic granitoids and sedimentary rocks occur in the TT in 175 Argentina and Uruguay (Gaucher et al., 2008; Abre et al., 2014) but are so far unknown in 176 the PAT. 
178 Uruguay and a key element for understanding the formation of West Gondwana. It is usually considered part of the Rio de la Plata Craton since the Mesoproterozoic (Hartmann et al. 2001; Gaucher et al., 2008, 2009b; Bossi \& Cingolani 2009; Santos et al., 2017), but other

181 studies have related the NPT to the Congo Craton, suggesting it was amalgamated to the Rio

182 de la Plata Craton only during the Ediacaran (Oyhantçabal et al. 2011; Rapela et al. 2011;

183 Oriolo et al. 2016a). The NPT presents a highly complex geology and the oldest rocks in

184 Uruguay, with major internal units limited by the NE-SW shear zones, a basement window

185 (Isla Cristalina de Rivera) cropping out far north in the Paraná Basin (Fig. 2), and continuity

186 to southernmost Brazil (Taquarembó Terrane) (Oyhantçabal et al. 2011, 2012; Bossi \&

187 Gaucher 2014b; Oriolo et al. 2016a, 2018). In a simplified way, the NPT is composed of the

188 Valentines Granulitic Complex in the northwest, the La China Complex and the Cebolatí

189 Group in the middle, and the Carapé Tectonic Slab and Mesoproterozoic volcano-

190 sedimentary successions in the southeast. The Valentines Complex, which includes the Isla

191 Cristalina de Rivera, comprises gneisses (felsic granulites), pyroxenites and banded iron

192 formations (BIF) as well as intruding tonalites, trondhjemites and granites with ages between

1932.6 and $2.2 \mathrm{Ga}$ (Santos et al., 2003; Oyhantcabal et al., 2012). They are in turn intruded by

194 the Illescas rapakivi granite, which yielded an U-Pb zircon age of $1.784 \mathrm{Ma}$ (Bossi et al.

195 1998; Bossi \& Cingolani 2009). The central domain includes the La China Complex, which

196 comprises metatonalites of amphibolite facies, and the metasedimentary Cebollatí Group

197 (formerly known under the informal term "Las Tetas complex"), both units with Archean 198 ages between 3.4 and $2.7 \mathrm{Ga}$ (Hartmann et al. 2001; Gaucher et al. 2010, 2011, 2014b). To

199 the southeast of the Archean units, a NE-trending belt of Mesoproterozoic (1.5-1.3 Ga), low200 grade meta-volcano-sedimentary rocks occurs, which includes the Parque UTE and Mina

201 Verdún groups and the Tapes Complex (Chiglino et al., 2010; Gaucher et al., 2011, 2014a; 
Poiré et al., 2005). At the southeastern corner of the NPT, the Carapé Complex, sometimes referred to as the Campanero Unit, is a tectonic slab emplaced in the NPT in the latest

Ediacaran-early Cambrian, and comprises mainly metagranitoids and metasediments juxtaposed by reverse and transcurrent faults (Hartmann et al. 2001; Mallmann et al. 2007; Chiglino et al. 2010, Bossi et al. 2014). Unconformably overlying parts of the NPT are remnants of the Arroyo del Soldado Group, a 5,000 m thick marine platform succession rich in carbonate deposits and with depositional age between 566 and $530 \mathrm{Ma}$ (Gaucher, 2000; Gaucher et al. 2004; Blanco et al. 2009).

211 allochthonous unit laterally accreted to the NPT during the Brasiliano/Pan-African Orogeny

212 (Bossi \& Gaucher 2004). This terrane is composed mainly of deformed calc-alkaline granitic

213 (e.g. Aiguá and Cuchilla Dionisio batholiths) with ages between 615 and $530 \mathrm{Ma}$, and occupies most of the CDT and is known in Brazil as the Pelotas Batholith (Fernandes et al. 1995; Bossi \& Gaucher 2004; Philipp et al. 2016). The Paleo-Mesoproterozoic Cerro Olivo

216 Complex occurs further east; it is considered the basement of this terrane and includes high-

217 grade metamorphic rocks with protolith ages between 1000 and $750 \mathrm{Ma}$, metamorphosed at $c$. 650 Ma (Bossi \& Gaucher 2004; Basei et al. 2011; Oyhantçabal et al. 2011; Peel et al. 2018; Will et al. 2019). Finally, near the South Atlantic coast the metasediments of the Rocha Group, are exposed. These have ages between c. 600 to $550 \mathrm{Ma}$ and affinity to units from the Kalahari Craton, being correlated to the Oranjemund Group of the Gariep Belt in Namibia (Bossi \& Gaucher 2004; Basei et al. 2005).

Although the discussion is still ongoing on how and when the tectonostratigraphic terranes of the UYS were assembled, there is a consensus that the long lived Brasiliano/PanAfrican Orogeny represents the final event for the consolidation of Uruguayan basement. The juxtaposition of UYS terranes, related to the diachronous collision of Uruguayan, Brazilian 
and African units, led to the formation of the West Gondwana megacontinent by Cambrian times (Bossi \& Gaucher 2004, 2014a). The successive collisions related to the

Brasiliano/Pan-African Orogeny were responsible for establishing sutures that later played an important role during Pangea breakup and South Atlantic opening in the Mesozoic (Oriolo et al. 2018; Schmitt et al. 2018; Will \& Frimmel 2018).

\subsection{Phanerozoic cover}

Most of the territory of Uruguay is covered by remnants of three Phanerozoic basins: the continentally wide intracratonic Paraná Basin, locally named the Norte Basin, and the relatively small and South Atlantic rift related Laguna Merin and Santa Lucia basins (Fig. 2). developed in the interior of West Gondwana during Paleozoic and Mesozoic times.

Depositional packages within this basin are divided into six supersequences separated by

239 interregional unconformities: Rio Ivaí (Ordovician to Silurian), Paraná (Devonian),

240 Gondwana I (Upper Carboniferous to Lower Triassic), Gondwana II (Middle to Upper

241 Triassic), Gondwana III (Jurassic to Lower Cretaceous), and Bauru (Upper Cretaceous)

242 (Milani 1997; Milani et al. 2007). The SE margin of the Paraná Basin lies within Uruguay

243 (Fig. 1), where basinal deposits cover most of the NW of the country and are associated with

244 the supersequences Paraná, Gondwana I and Gondwana III, reaching a maximum thickness between 2,300 and 3,000 m (de Santa Ana et al 2006). The lowermost deposits correspond to the Durazno Group, cropping out at the SE margin of the basin and related to the Paraná

247 Supersequence. This group comprises a transgressive-regressive siliciclastic sequence of

248 shallow marine deposits, with paleocurrents to the NW and sourced from the UYS terranes,

249 being deposited within an extensional subsidence regime (Sprechmann et al. 1993; Uriz et al.

250 2016). Separated by an unconformity, the overlying depositional sequence Gondwana I

251 Supersequence represents a transgressive-regressive cycle as well. It comprises latest 
252 Carboniferous to Permian deposits that record the transition from glaciolacustrine, to marine

253 and finally fluvial and aeolian environments (de Santa Ana et al. 2006; Beri et al. 2011).

254 Last, unconformably above these, lies the continental deposits of the Gondwana III

255 Supersequence, which comprises fluvial and aeolian formations capped by basalt flows from

256 the Paraná-Etendeka Large Igneous Province (LIP) (Sprechmann et al., 1981), with eruption

257 peak at c. $133 \mathrm{Ma}$ and related to the Tristão da Cunha mantle plume and the opening of the

258 South Atlantic (Turner et al. 1994; Rossetti et al. 2014; Cernuschi et al. 2015).

259 The tectonic stress associated with Pangea breakup and Atlantic opening led to the

260 development of the Santa Lucia and Laguna Merin basins onshore (Bossi et al. 1998), which

261 form a ENE-WSW corridor known as SaLAM, that is considered an aborted rift precursor to

262 the opening of the South Atlantic during the Jurassic-Cretaceous (Rossello et al. 2000).

263 Despite the genetic link, the basins present distinct volcano-sedimentary infill and are

264 separated by the NPT, where only smaller rift basins are found (Rossello et al. 2000). The

265 SaLAM was formed during extensional tectonics related to Pangea breakup, with a later

266 dextral transtensive phase associated by (Rossello et al. 2000, 2007) with the drifting

267 movement that led to the completion of South Atlantic opening. The Santa Lucia Basin

268 corresponds to the SW part of the SaLAM, presents a central structural high with E-W strike

269 and comprises mostly siliciclastic deposits, reaching a total thickness of 2,500 m (Rossello et

270 al. 2000; Veroslavsky et al. 2004). The NE SaLAM is represented by the Laguna Merin

271 Basin, which is mainly composed of volcanic rocks with ages between 134 to $127 \mathrm{Ma}$ and

272 covered by Cenozoic sedimentary rocks (Cernuschi et al. 2015). The youngest volcanic rocks

273 so far described in Uruguay are subalkaline rhyolites in southern NPT, dated U-Pb SHRIMP

274 by Gaucher et al. (2016) at $77 \pm 1 \mathrm{Ma}$ (Campanian, Late Cretaceous). 


\section{Materials and methods}

276

277

278

280

281

282

283

284

\subsection{Sampling}

For this study we collected basement samples from 32 outcrops across Uruguay. We avoided locations with published low-temperature thermochronometry data and aimed to cover most of the shield, collecting samples from the margins and central parts of each tectonostratigraphic terrane. Standard crushing, magnetic and heavy liquids separation were processes applied to separate apatite and zircon crystals. Although we sampled mainly granitic rocks, which are usually rich in apatite and zircon, only 21 samples provided crystals suitable for the thermochronometry analysis (Fig. 2, Tab. 1).

\begin{tabular}{|c|c|c|c|c|c|c|c|}
\hline Sample & Lithology & Age $(\mathrm{Ma})$ & Lat $\left({ }^{\circ}\right)$ & Long $\left({ }^{\circ}\right)$ & Altitude $(\mathrm{m})$ & D. sea $(\mathrm{km})$ & Analysis \\
\hline UY1 & Granite & $>550$ & -31.89 & -54.16 & 225 & 181 & AFT, AHe \\
\hline UY2 & Granite & $575 \pm 14$ & -32.35 & -53.79 & 110 & 133 & AFT, AHe, ZHe \\
\hline UY6 & Granite & $590-530$ & -31.59 & -55.10 & 259 & 277 & AFT, AHe \\
\hline UY7 & Granite & $550-510$ & -31.75 & -55.18 & 208 & 278 & AFT \\
\hline UY8 & Granite & $590-530$ & -31.55 & -55.49 & 193 & 312 & AFT, AHe, ZHe \\
\hline UY10 & Granite & $>1000$ & -33.12 & -55.13 & 245 & 173 & AFT, ZHe \\
\hline UY11 & Granite & $1785 \pm 9$ & -33.61 & -55.33 & 235 & 161 & AFT, AHe \\
\hline UY13 & Granite & $>1000$ & -33.28 & -54.62 & 102 & 120 & ZHe \\
\hline UY14 & Granite & $590-530$ & -33.99 & -54.78 & 131 & 89 & AFT, AHe \\
\hline UY16 & Granite & $c .2200$ & -34.06 & -55.31 & 266 & 104 & AFT, AHe \\
\hline UY18 & Gnaisse & $c .2200$ & -34.92 & -56.17 & 150 & 111 & AFT, AHe, ZHe \\
\hline UY19 & Granite & $2054 \pm 11$ & -34.67 & -55.64 & 55 & 69 & AFT \\
\hline UY21 & Granite & $574 \pm 34$ & -34.41 & -55.25 & 182 & 66 & AFT, AHe \\
\hline UY24 & Gnaisse & $1006 \pm 37$ & -34.97 & -54.95 & 9 & 0 & AHe \\
\hline UY25 & Diorite & $2065 \pm 9$ & -34.19 & -56.32 & 54 & 153 & AFT, AHe \\
\hline UY26 & Granite & $c .2100$ & -34.10 & -56.20 & 47 & 150 & AFT \\
\hline UY27 & Granite & $c .2200$ & -33.96 & -56.24 & 133 & 163 & AFT, AHe, ZHe \\
\hline UY29 & Granite & $>550$ & -34.85 & -54.63 & 7 & 0 & AFT, ZHe \\
\hline UY30 & Schist & $<1540$ & -34.59 & -54.12 & 3 & 0 & AFT, AHe \\
\hline UY31 & Granite & $556 \pm 7$ & -34.11 & -53.85 & 71 & 17 & AFT \\
\hline UY32 & Granite & $678 \pm 14$ & -34.04 & -53.54 & 4 & 0 & AFT, AHe, ZHe \\
\hline & & & & & & & \\
\hline
\end{tabular}

Table 1: Details of each location and analysis made. Stratigraphic ages from Bossi \& Gaucher (2004) and Masquelin (2006); coordinates in degrees and datum WGS84; (D. sea) is the shortest distance to the Atlantic Ocean.

\subsection{Low-temperature thermochronometry}

We used three low-temperature thermochronometers to investigate the thermal evolution of the Uruguayan basement: apatite fission-tracks (AFT), apatite (U-Th)/He (AHe) and zircon $(\mathrm{U}-\mathrm{Th}) / \mathrm{He}(\mathrm{ZHe})$. These radio-isotopic systems have distinct retention 
temperatures, and together cover an interval between $c .40$ to $190^{\circ} \mathrm{C}$, simply put, shallow crust temperatures. Each method has its specific partial retention zone (PRZ), which corresponds to a temperature interval where accumulation and loss of the radiogenic decay product are coeval. Temperatures lower than the PRZ of the thermochronometer appraised

296 imply total retention of the radiogenic products, while higher temperatures than the PRZ

297 result in complete loss of them, resetting the age of the thermochronometer to zero.

298 Therefore, the age obtained by thermochronometry methods is a cooling age, based on the balance between radiogenic parent and decay product, and represents a time-temperature

300 point during the passage through the PRZ of the thermochronometer. Apatite fission-tracks thermochronometry is based on the accumulation of linear

302 defects (tracks) in the crystal lattice, formed by spontaneous fission of ${ }^{238} \mathrm{U}$ and which the quantity and variable lengths indicates the thermal path experienced by the crystal (Price \& Walker 1963; Fleischer et al. 1975; Gleadow et al. 1986a, b; Galbraith et al. 1990). The apatite fission-track partial retention zone (AFTPRZ) corresponds to temperatures between $c$. 60 to $110^{\circ} \mathrm{C}$, in which the tracks slowly shrink in a process known as annealing (Wagner et al. 1989). Below c. $60^{\circ} \mathrm{C}$ the annealing process is not effective, and tracks are preserved with their full initial length $(c .16 \mu \mathrm{m})$. Although temperature is the main factor controlling annealing, this process is also affected by variations in apatite chemical composition and the amount of accumulated radiation damage (Gleadow et al. 1986a; Stockli 2005; Tagami \&

311 O’Sullivan 2005). We used the external detector method for AFT dating (Gleadow 1981; Hurford 1990).

313 For each sample, more than 200 apatites were hand-picked and mounted in epoxy resin

314 tablets, polished to the central portion, and etched in a $5.5 \mathrm{M} \mathrm{HNO} 3$ solution at $21^{\circ} \mathrm{C}$ for $20 \mathrm{~s}$

315 to reveal the spontaneous fission tracks (Carlson et al. 1999). Muscovite sheets were coupled 316 to the tablets, which then were irradiated at the IEA-R1/IPEN-CNEN Reactor, São Paulo, 
317 Brazil, along with Durango age standards and Corning CN5 dosimeters. Afterwards, mica

318 sheets were decoupled and etched in $48 \% \mathrm{HF}$ for $18 \mathrm{~min}$ at $20^{\circ} \mathrm{C}$ to reveal the induced tracks.

319 AFT analyses were performed at the Universidade Federal do Rio Grande do Sul, Brazil,

320 using a Leica DM 6000 M Microscope (1000x, dry). Ages were calculated based on 20

321 crystals per sample and the $\zeta$ calibration method (Hurford \& Green 1983; Hurford 1990),

322 while ages homogeneity was analyzed through the chi-square test (Galbraith 1981; Galbraith

323 \& Green 1990) using the software RadialPlotter 9.0 (Vermeesch 2009). For thermal modeling

324 we aimed to measure lengths and $c$-axis angles of 100 confined TINT tracks (Lal et al. 1969)

325 in each sample, and used the mean etch pit diameter $\mathrm{D}_{\text {par }}$ from about 100 measurements as

326 kinetic parameter (Donelick 1993; Carlson et al. 1999; Donelick et al. 2005).

The (U-Th)/He method is based in the accumulation of alpha particles $\left({ }^{4} \mathrm{He}\right)$ in the crystal lattice after the decay chain of ${ }^{238} \mathrm{U},{ }^{235} \mathrm{U}$ and ${ }^{232} \mathrm{Th}$ isotopes. The alpha particles are expelled from the mineral structure at high temperatures owing to thermal diffusion. In apatite (U-Th)/He dating, alpha particles are efficiently expelled at temperatures above $c$. $70^{\circ} \mathrm{C}$, partially retained between c. 40 and $70^{\circ} \mathrm{C}$ (AHe Partial Retention Zone - AHePRZ), and completely retained when temperature is below c. $40^{\circ} \mathrm{C}$ (Wolf et al. 1996, 1998; Farley 2002). However, these temperature limits are known to vary with crystal dimensions, compositional zonation, eU concentration $(\mathrm{eU}=[\mathrm{U}]+0.235 \times[\mathrm{Th}])$ and accumulated radiation damage (Farley 2000; Reiners \& Farley 2001; Shuster et al. 2006). Moreover, small

336 fluctuations in these factors are magnified by extended residence in the AHePRZ, commonly

337 resulting in dispersed AHe ages (Flowers \& Kelley 2011). In zircon (U-Th)/He dating, alpha particles are partially retained between $c .150$ and $190^{\circ} \mathrm{C}$ (ZHe Partial Retention Zone ZHePRZ), and promptly expelled at temperatures higher than $190^{\circ} \mathrm{C}$ (Reiners et al 2018 book). Similarly to AHePRZ, the ZHePRZ is affected by compositional zonation, eU 
341 concentration, accumulated radiation damage and protracted residence at low temperatures

342 (Reiners et al. 2002, 2004; Nasdala et al. 2004; Reiners 2005).

344 Dating Laboratory (BARHDL), at the University of Arizona, US. Both apatites and zircons

345 were handpicked based on morphology, size and optical clarity, using a Leica MZ16

346 microscope. Because apatites tend to accumulate low quantity of alpha particles due the low

$347 \mathrm{eU}$ concentration $(\mathrm{eU}<50 \mathrm{ppm})$, preference was given to clear apatites with both

348 terminations, aiming to avoid crystals that loss ${ }^{4} \mathrm{He}$ through fractures or a highly damaged

349 crystal lattice. On the other hand, since zircon eU usually is one or two orders of magnitude

350 higher, we picked zircons with a wide range of opacity, which ultimately reflect the amount

351 of accumulated radiation damage, and provide a better view of the eU influence over the $\mathrm{ZHe}$

352 age. Crystals were measured and photographed with Leica Application Suite V3, to define

353 the diffusion domain and allow the alpha-ejection age correction (Farley et al. 1996), which

354 accounts for the ejection of ${ }^{4} \mathrm{He}$ in crystal rims during decay. $\mathrm{Nb}$ foil tubes were used to pack

355 the crystals for helium extraction, made using long-wavelength laser heating and measured

356 with a quadrupole mass spectrometer. Subsequently, crystals were dissolved for the U-Th

357 measurements, performed using a high-resolution Element2 ICP-MS. Durango standards and

358 blank samples were systematically introduced in between analysis to guarantee reliability of

359 the measurements.

\subsection{Inverse thermal modeling}

The thermal history of each sample was recreated using the program QTQt 5.7, which

362 tests time-temperature points aiming to reconstruct a thermal history that predicts and

363 reproduces the observed thermochronometric data (Gallagher et al. 2009; Gallagher 2012).

364 We opted to run models with a minimum of user-imposed constraints, to avoid a biased

365 thermal history. To initiate our models, a large t-T box was set with time ranging from $500 \pm$ 
$36650 \mathrm{Ma}$ and temperature from $100 \pm 100^{\circ} \mathrm{C}$, time corresponding to the end of the

367 Brasiliano/Pan-African. A final constraint was set with temperature of $20 \pm 10^{\circ} \mathrm{C}$ at the

368 present time. The thermal history between initial and final constraints was recreated freely by

369 QTQt 5.7, using a temperature range of $70 \pm 70^{\circ} \mathrm{C}$ when modeling only AFT and AHe, and

370 up to $100 \pm 100^{\circ} \mathrm{C}$ when $\mathrm{ZHe}$ data were available.

371 Because our current understanding of the AFT system is arguably better established

372 than the (U-Th)/He system, trial models were run only with AFT data at first, and (U-Th)/He

373 data were included in posterior models. Several fast runs of 20,000 interactions were made

374 initially for each sample to set appropriate parameters during inversion (see Gallagher, 2012),

375 and to test the variability of models using different $\partial \mathrm{T} / \partial \mathrm{t}$ rates. Models run only with AFT

376 data resulted in good fit between observed and predicted ages and MTL, but the inclusion of

377 AHe data into the models led to a considerable mismatch of the AFT data. The later models

378 predicted older AFT ages than the observed while attempting (and usually failing) to fit all

379 AHe ages without improving the low temperature $\left(<60^{\circ} \mathrm{C}\right)$ thermal history. To address this

380 conflict and maintain a good fit of our AFT data, we used a feature from QTQt 5.7 that

381 resamples the AHe age error in order to accept a larger degree of mismatch of AHe data. On

382 the other hand, the inclusion of ZHe data usually better constrained the cooling time from

383 higher temperatures $\left(>150^{\circ} \mathrm{C}\right)$ in the models. Final models combined all thermochronometry

384 data available for each sample, were run for 200,000 interactions or more, and used a

385 maximum $\partial \mathrm{T} / \partial \mathrm{t}$ of $10^{\circ} \mathrm{C} / \mathrm{Ma}$, compatible with a cratonic region of subdued topography. This

386 final modeling set up permitted the proposed time-temperature paths to be well defined but

387 not tightly limited by our constraints or by the old and dispersed AHe ages (see Results and

388 Interpretations). During modeling, for AFT we used the $\mathrm{D}_{\text {par }}$ values and $c$-axis projected

389 tracks lengths (Donelick 1993; Donelick et al. 1999a), the AFT annealing model from 
390 Ketcham et al. (2007), and the radiation damage model from Flowers et al. (2009) for AHe

391 and from Guenthner et al. (2013) for ZHe.

\section{Results of previous thermochronometry studies in Uruguay}

The first thermochronometry investigation in the UYS was made by Kollenz (2015),

who obtained seven AFT ages in the shield. Five AFT central ages in the PAT and TT range between $325 \pm 25$ and $200 \pm 20 \mathrm{Ma}$, with a mean of $260 \mathrm{Ma}$, and show a tendency to increase with the distance from the coast, although the youngest age is in the middle of the PAT. The remaining two ages, around $225 \mathrm{Ma}$, were obtained in the western part of the CDT. Track lengths were obtained from four samples from PAT, TT and CDT and display a unimodal distribution, with a range between 12.2 and $10.8 \mu \mathrm{m}$. Inverse thermal modeling made in these four samples using HeFTy (Ketcham 2005), show general cooling from the high limit of the AFTPRZ to surface temperature between the Carboniferous and Middle Jurassic, followed by a period of reheating until Late Cretaceous, when some samples reached temperatures up to $65{ }^{\circ} \mathrm{C}$. A final cooling back to surface temperature was observed in all models during the Cenozoic. According to Kollenz (2015) the Paleozoic to Mesozoic cooling trend is linked to a regional exhumation, possibly related to compressional stress in the SW of Gondwana (e.g. Gondwanic cycle) and which has been also reported further south in Argentina and north in southernmost Brazil (Borba et al. 2002, 2003; Oliveira et al. 2016; Kollenz et al. 2017; Machado et al. 2019). They suggest that the late Mesozoic reheating phase is associated to the Paraná-Etendeka LIP, which lava flows would have buried the UYS and caused an increase in the bedrock temperature. ages present a range from $326 \pm 30$ to $121 \pm 19 \mathrm{Ma}$ (if an outlier of $38 \pm 2 \mathrm{Ma}$ is ignored),

413 suggest a positive correlation with altitude and are divided by the authors into a western 414 domain of older ages and an eastern domain of younger ages. The MTL show a unimodal 
415 distribution and range from 12.5 to $10.0 \mu \mathrm{m}$. Inverse thermal modeling was made in eight

416 samples using the outdated AFTSolve (Ketcham et al. 2000), a software without $c$-axis

417 projected track lengths, and a limited number of confined tracks (usually $<45$ ), so that the

418 resulting models should be taken carefully. In any case, they suggest a general cooling trend

419 until the Triassic, when samples reached stability around the lower limit of the AFTPRZ (60

$420{ }^{\circ} \mathrm{C}$ ). Some of their samples in Uruguay and southernmost Brazil suggest reheating during

421 Cretaceous. All models show a final cooling to surface temperature after the Paleogene.

Based on a dataset of AHe and ZHe ages, Hueck et al. (2017) suggested a distinct

thermal evolution for the UYS. They obtained 33 ZHe ages from 11 locations, with average ages between 560 and $460 \mathrm{Ma}$ and acquired within zircons mostly of eU $<500 \mathrm{ppm}$. ZHe ages do not show correlation with eU, crystal size, altitude or location. Their AHe ages were obtained from 27 crystals from nine locations and show considerable dispersion, with mean ages ranging from Permian to Cretaceous. No correlation was found between AHe ages and eU or crystal size, but it is suggested that samples from the southern UYS, closer to the coast, have the youngest values. From inverse thermal models made in HeFTy, the authors suggest that the UYS reached near-surface conditions by Silurian (c. $420 \mathrm{Ma}$ ), succeeded by cycles of burial (and minor reheating) and erosion, associated to Devonian and Permian Paraná Basin deposits. Their models imply a final Mesozoic exhumation of the UYS, with restricted sedimentation, and possibly related to the tectonic stress associated with Pangea breakup.

434 According to the authors, by the end of Mesozoic the analyzed samples would have reached surface temperature, and a Cretaceous reheating is not supported.

In summary, Kollenz (2015) models based on AFT support cooling towards near437 surface conditions $\left(\mathrm{T}<30^{\circ} \mathrm{C}\right)$ from Carboniferous to Jurassic, followed by reheating (up to $43865^{\circ} \mathrm{C}$ ) in the Cretaceous and a final cooling to surface temperature during Cenozoic. Gomes 439 \& Almeida (2018) AFT models suggest a major cooling phase until the Triassic, without 
reaching near-surface conditions and followed by stability around $60{ }^{\circ} \mathrm{C}$ or minor reheating

441 during the late Mesozoic, until a final cooling phase starting in the Miocene. On the other

442 hand, Hueck et al. (2017) (U-Th)/He models suggest cooling to near-surface conditions by

443 the Silurian, followed by shallow reburial (with reheat below $90^{\circ} \mathrm{C}$ ) and exhumation cycles

444 until Permian and a final cooling to surface temperature during Mesozoic. Despite the

445 temporal conflict, all authors support a complex thermal history for the region, with a main

446 Paleo- Mesozoic cooling phase to temperatures close or below $60^{\circ} \mathrm{C}$, minor reheating

447 episodes or protracted stability at this temperature, and a final Meso- Cenozoic cooling

448 towards surface temperature. Remarkably, their models were made using different data and

449 user constraints, and their cooling/heating phases imply distinct thermotectonic histories for 450 the UYS.

\section{Results and interpretations}

The results from each thermochronometer and from the inverse modeling are exposed in the subsections below. General interpretations are briefly commented as well, however the particularities of the results inserted in the geological context on Uruguay are explored in the Discussion section.

\subsection{Apatite Fission-tracks}

We obtained AFT ages from 19 samples (Table 2), all of which passed the homogeneity chi-square test $\left(\mathrm{P} \chi^{2}>5 \%\right)$ and generally did not show single grain age dispersion, which means that the central ages obtained correspond to single populations.

460 Three samples presented minor age dispersion (UY10 $=17 \%$, UY19 $=18 \%$ and UY32 $=$ $46118 \%$ ) that could indicate a mix of apatite populations, but because they passed the chi-square test and their central ages agree with neighborhood samples, we considered them as single 
situated in the Jurassic Period. In general, the younger ages are near the coast or structural

466 lineaments, while the older ones are hinterland, in a common distribution of ages of passive

467 margins (Gallagher \& Brown 1997). When including data from previous AFT studies in the

468 region, a positive correlation between ages and elevation or distance to the Atlantic Ocean is

469 observed (Fig. 3). The NPT presented simultaneously one of the oldest AFT age in our set

470 (sample UY6 with c. $230 \mathrm{Ma}$, located in the north on the Isla Cristalina de Rivera) and also

471 the youngest AFT age (UY14 with c. $85 \mathrm{Ma}$, in the southern-central portion of the terrane).

472 This deviation can be related to the complexity of the NPT, composed of distinct rock

473 associations and cut by several faults and shear zones, prone to variable exhumation within

474 the terrane. Sample UY14 for example, the youngest one, is located near a major fault, and

475 might reflect the last stage of tectonic reactivation of this structure at the time of Campanian

476 rhyolitic volcanism (Gaucher et al., 2016).

477
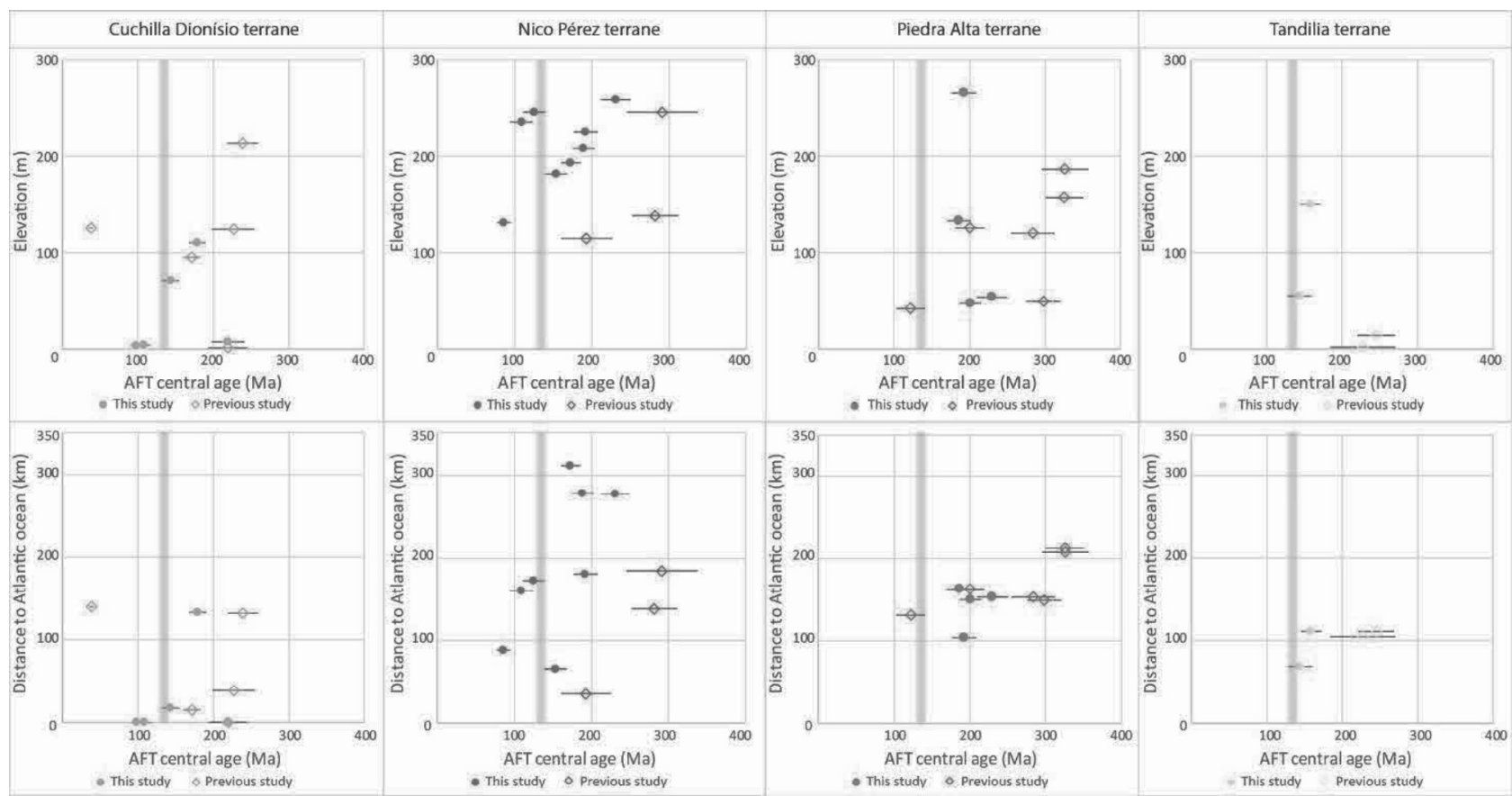

Figure 3. Compilation of AFT data available for the Uruguayan shield. Top row shows plots of AFT 
484 short, ranging from $12.7 \pm 0.2$ to $10.2 \pm 0.2 \mu \mathrm{m}$ (Table 2). After applying the $c$-axis 485 projection (Donelick et al. 1999b), the MTL range from 13.9 to $12.3 \mu \mathrm{m}$, with standard 486 deviation between 1.4 and $0.8 \mu \mathrm{m}$. The lengths scattering tends to be unimodal for all 487 samples but UY29, which displays a bimodal distribution and a distinct old AFT age in SSE 488 coastal region (CDT). In most cases, the track lengths distribution is Gaussian around the 489 mean value or negatively skewed, with a larger proportion of longer tracks (see 490 Supplementary Material), which can be interpreted in terms of protracted cooling (Gallagher 491 \& Brown 1999). A plot of the MTLs against AFT central ages (Fig. 4), including published 492 data (Kollenz 2015; Gomes \& Almeida 2019), does not show a clear "boomerang" shape 493 (Green 1986), which is characteristic of reheating with partial reset of AFT ages in a region. 494 Instead it suggests that samples went through protracted cooling without a major reheating, 495 and with distinct parts of the shield cooling below $110^{\circ} \mathrm{C}$ at different times. Measurements of 496 the $\mathrm{D}_{\text {par }}$ range between 2.27 and $1.76 \mu \mathrm{m}$, which indicates a predominance of chlorine rich 497 apatites, with high resistance to annealing (Carlson et al. 1999; Donelick et al. 2005). 

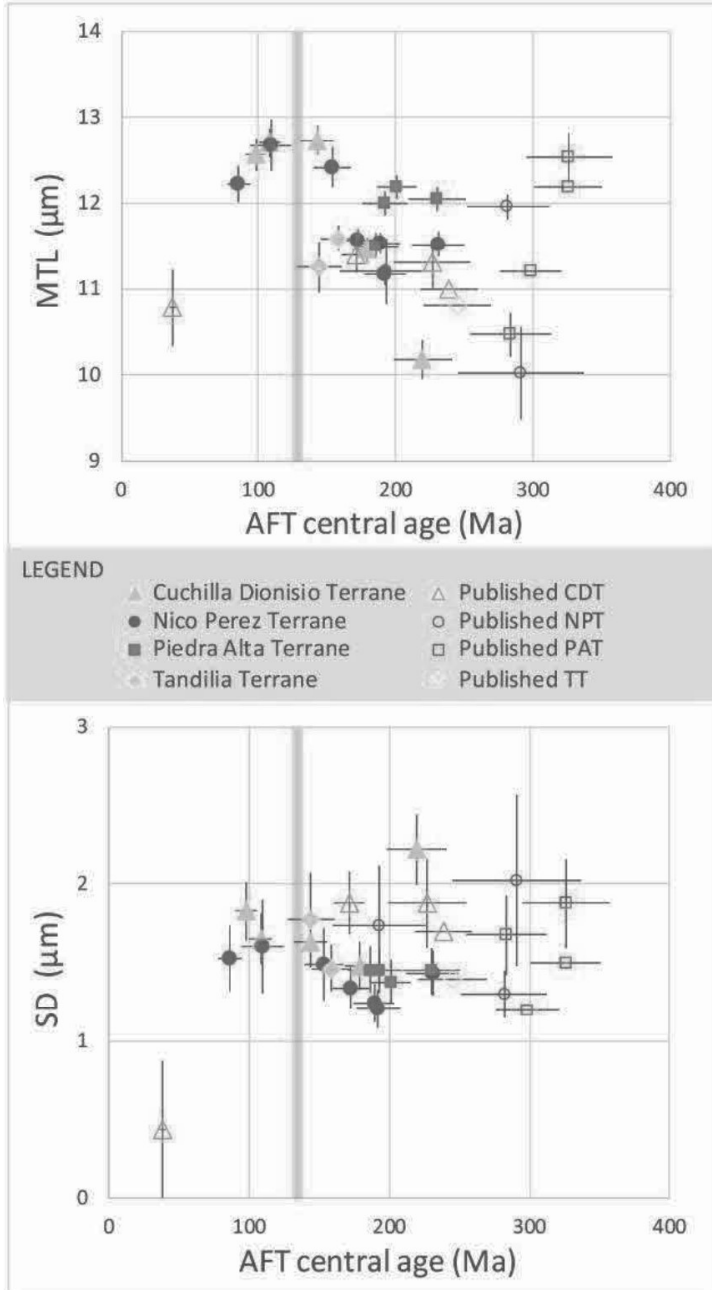

Figure 4. Compilation of AFT data available for the Uruguayan shield. In the top, AFT central ages against MTLs uncorrected for their c-axis orientation, suggesting that samples went through protracted cooling without partial resetting during the Paraná-Etendeka LIP volcanism (vertical red bar), and with distinct parts of the shield cooling below $110^{\circ} \mathrm{C}$ at different times. In the bottom, plot of the AFT central ages against the standard deviation of the MTLs, which also does not show a "boomerang" shape. Error bars represent $\pm 1 \sigma$ 504 range. 


\begin{tabular}{|c|c|c|c|c|c|c|c|c|c|c|c|c|c|c|c|c|c|c|}
\hline \multicolumn{19}{|c|}{ Apatite Fission Tracks analysis } \\
\hline Sample & $\mathrm{N}$ & ps & Ns & $\rho i$ & $\mathrm{Ni}$ & $\rho d$ & $\mathrm{Nd}$ & Central Age & $\pm 1 \sigma$ & $x^{2}$ & $\mathrm{u}$ & Dpar & CT & MTL & $\pm 1 \sigma$ & SD & CP. MTL & cP. SD \\
\hline$\#$ & $\#$ & $\left(\times 10^{5}\right)$ & $\#$ & $\left(\times 10^{5}\right)$ & $\#$ & $\left(\times 10^{5}\right)$ & $\#$ & (Ma) & (Ma) & (\%) & (ppm) & $(\mu \mathrm{m})$ & $\#$ & $(\mu \mathrm{m})$ & $(\mu \mathrm{m})$ & $(\mu \mathrm{m})$ & $(\mu \mathrm{m})$ & $(\mu \mathrm{m})$ \\
\hline \multicolumn{19}{|c|}{ Cuchilla Dionísio Terrane } \\
\hline UY2 & 20 & 18.91 & 779 & 10.46 & 431 & 7.17 & 14341 & 179.0 & 10.8 & 88 & 18.5 & 1.87 & 100 & 11.46 & 0.15 & 1.48 & 13.31 & 0.90 \\
\hline UY29 & 20 & 9.16 & 338 & 4.12 & 152 & 7.17 & 14341 & 219.6 & 21.5 & 99 & 7.3 & 1.79 & 100 & 10.18 & 0.22 & 2.22 & 12.31 & 1.39 \\
\hline UY30 & 20 & 12.96 & 359 & 12.85 & 356 & 7.00 & 13999 & 98.1 & 7.4 & 69 & 23.3 & 2.18 & 100 & 12.57 & 0.18 & 1.83 & 13.89 & 1.43 \\
\hline UY31 & 20 & 15.5 & 369 & 10.76 & 256 & 7.17 & 14341 & 143.2 & 11.7 & 94 & 19.1 & 2.04 & 100 & 12.73 & 0.16 & 1.63 & 13.93 & 1.31 \\
\hline UY32 & 20 & 15.14 & 542 & 13.85 & 496 & 7.17 & 14341 & 108.3 & 8.1 & 11 & 24.5 & 1.91 & 100 & 12.71 & 0.17 & 1.65 & 14.08 & 1.07 \\
\hline \multicolumn{19}{|c|}{ Nico Pérez Terrane } \\
\hline UY1 & 20 & 19.25 & 460 & 9.92 & 237 & 7.17 & 14341 & 192.1 & 15.4 & 99 & 17.6 & 1.82 & 100 & 11.17 & 0.12 & 1.21 & 13.00 & 0.80 \\
\hline UY6 & 20 & 12.29 & 515 & 5.25 & 220 & 7.17 & 14341 & 230.9 & 18.7 & 95 & 9.3 & 1.88 & 100 & 11.52 & 0.14 & 1.44 & 13.31 & 0.88 \\
\hline UY7 & 20 & 17.97 & 532 & 9.19 & 272 & 7.00 & 13999 & 189.0 & 14.2 & 98 & 16.7 & 1.81 & 100 & 11.53 & 0.12 & 1.25 & 13.24 & 0.84 \\
\hline UY8 & 20 & 13.24 & 507 & 7.60 & 291 & 7.17 & 14341 & 172.7 & 12.8 & 99 & 13.5 & 1.90 & 100 & 11.56 & 0.13 & 1.34 & 13.30 & 0.83 \\
\hline UY10 & 20 & 4.06 & 204 & 3.17 & 159 & 7.00 & 13999 & 125.4 & 14.1 & 59 & 5.7 & 1.87 & - & - & - & - & - & - \\
\hline UY11 & 20 & 5.3 & 114 & 4.84 & 104 & 7.17 & 14341 & 109.2 & 14.8 & 100 & 8.6 & 1.79 & 30 & 12.68 & 0.29 & 1.61 & 13.87 & 1.23 \\
\hline UY14 & 20 & 3.47 & 191 & 4.05 & 223 & 7.17 & 14341 & 85.8 & 8.4 & 100 & 7.2 & 1.88 & 52 & 12.23 & 0.21 & 1.53 & 13.72 & 1.16 \\
\hline UY21 & 20 & 8.39 & 308 & 5.42 & 199 & 7.17 & 14341 & 153.6 & 14.0 & 94 & 9.6 & 1.87 & 42 & 12.43 & 0.23 & 1.49 & 13.84 & 1.04 \\
\hline \multicolumn{19}{|c|}{ Piedra Alta Terrane } \\
\hline UY16 & 20 & 10.71 & 422 & 5.38 & 212 & 7.00 & 13999 & 192.3 & 16.3 & 100 & 9.8 & 1.76 & 100 & 12.00 & 0.15 & 1.45 & 13.58 & 0.99 \\
\hline UY25 & 20 & 18.78 & 417 & 8.06 & 179 & 7.17 & 14341 & 229.9 & 20.6 & 82 & 14.3 & 1.99 & 100 & 12.05 & 0.14 & 1.45 & 13.54 & 1.10 \\
\hline UY26 & 20 & 22.09 & 612 & 10.87 & 301 & 7.17 & 14341 & 201.1 & 14.3 & 74 & 19.2 & 2.27 & 100 & 12.20 & 0.14 & 1.38 & 13.73 & 0.87 \\
\hline UY27 & 20 & 12.69 & 387 & 6.59 & 201 & 7.00 & 13999 & 186.1 & 16.2 & 99 & 12.0 & 2.03 & 100 & 11.50 & 0.15 & 1.46 & 13.18 & 1.04 \\
\hline \multicolumn{19}{|c|}{ Tadilia Terrane } \\
\hline UY18 & 20 & 13 & 360 & 7.94 & 220 & 7.00 & 13999 & 158.5 & 13.6 & 100 & 14.4 & 1.77 & 100 & 11.59 & 0.15 & 1.47 & 13.30 & 0.95 \\
\hline $2 \$ 19$ & 20 & 13.79 & 222 & 9.63 & 155 & 7.17 & 14341 & 144.0 & 16.2 & 53 & 17.1 & 1.86 & 38 & 11.25 & 0.29 & 1.78 & 13.08 & 1.11 \\
\hline
\end{tabular}

506 Table 2: Apatite fission-track data from the Uruguayan shield. Ages were calculated using $\zeta=$

507 280.17. N: number of grains analyzed; $\rho$ s: spontaneous track density; Ns: number of spontaneous

508 tracks counted; $\rho$ i: induced track density; Ni: number of induced tracks counted; $\rho$ d: dosimeter tracks

509 density; Nd: number of tracks used to determine $\rho d ; \chi 2$ : chi-square probability of single population;

510 U: estimated value of uranium content; Dpar: mean etch pit diameter; CT: confined tracks measured;

511 MTL: mean track length; SD: standard deviation of mean track length distribution; CP.MTL: c-axis

512 projected mean track length; cP. SD: standard deviation of c-axis mean track lenght; (-): data not

513 available.

514 5.2 Apatite (U-Th)/He

515 Apatites from 14 locations were selected for AHe analysis, in total representing 42

516 single crystal ages (Table 3 ). The obtained ages present are widely dispersed, not only

517 between samples and terranes, but also among apatites from each sample, in a similar way as

518 observed by Hueck et al. (2017). The AHe uncorrected ages range throughout the

519 Phanerozoic, but the majority of them are Mesozoic. No reduction in the age dispersion is

520 observed after applying the Ft correction (Farley et al. 1996). Furthermore, the AHe ages 
521 obtained are mostly older than the AFT ages from the same location, portraying an inverse pattern that is often observed in cratonic regions (Flowers \& Kelley 2011).

524 the crystal radius and integrity (Reiners \& Farley 2001; Brown et al. 2013), and of the 525 effective uranium (eU) content of crystals (Flowers et al. 2007), factors that commonly affect

526 AHe ages. Our samples do not show a clear correlation between ages and these parameters, suggesting that other factors are responsible for the AHe ages dispersion. Several variables can influence AHe ages, including U and Th zonation (Farley et al. 1996; Flowers \& Kelley 2011), U-rich inclusions (Stockli et al. 2000), ${ }^{4} \mathrm{He}$ implantation from U-rich neighbor

530 minerals and phases (Murray et al. 2014), accumulated radiation damage on the crystal lattice

531 (Green \& Duddy 2006; Shuster et al. 2006), among others - see Wildman et al. (2016) for a summary of the influence of these and others factors. These variables can be used to explain the dispersion in some samples, as in sample UY2, collected from a region of eU rich granites and that present old AHe ages and high values of ${ }^{4} \mathrm{He}$ for its eU content, making ${ }^{4} \mathrm{He}$ implantation or U-rich inclusions likely occurrences. Figure 5 shows apatites from samples UY8, UY27 and UY32 that were subjected of AFT analysis and exhibits zonation and inclusions. Although the images are not from crystals used for AHe dating, they represent common features in these samples that potentially affected our AHe ages. Considering this, we opted to report in Figure 2 the youngest AHe age for each location, which potentially

540 represents the age least affected by factors such as implantation and inclusions. As such,

541 these would be closer to the actual cooling age of the sample and correspond to the standard 542 closure temperature (Dodson 1973) of the AHe system. The presence of inclusions, zonation or defects in the crystal lattice can lead to the highly dispersed ages and mask the common

544 correlations between ages and eU or crystal radius. However, because dispersion is observed 
545 in most of our samples, a more general approach is desired to explain our results, as

546 suggested later in the Discussion section.

547

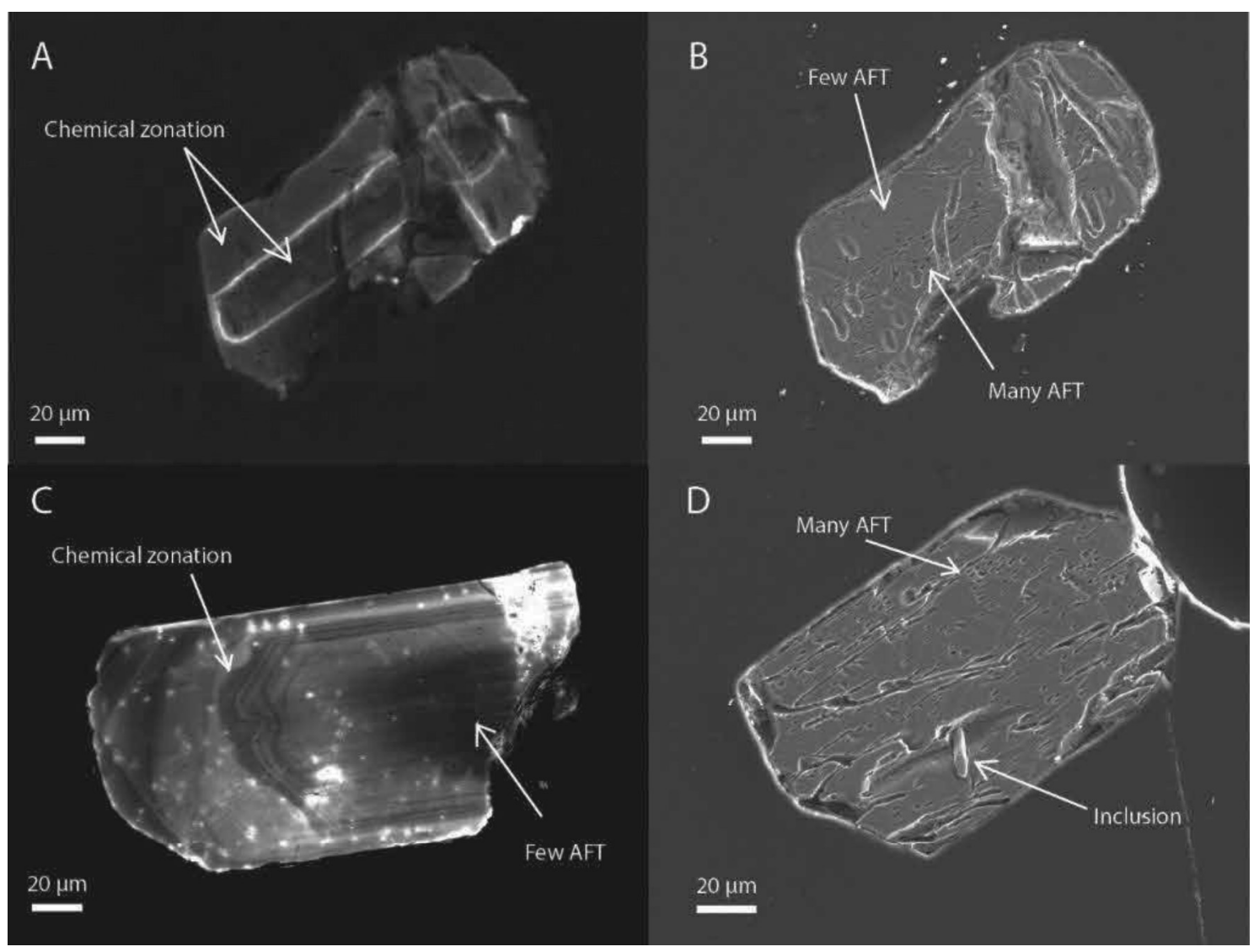

Figure 5. Photomicrographs of apatites showing factors that can affect the ( $U-T h / H e)$ analysis and cause significant age inaccuracies. $(A, B)$ Cathodoluminescence and secondary electron images from the same apatite from UY32 showing a brightly marked chemical zonation coincident with a fission-track density zonation. (C) Cathodoluminescence from apatite from UY8 showing chemical zonation and a low density of tracks in the center. (D) Secondary electron image from apatite from UY27 showing inclusion and a higher density of tracks in the rims. 


\begin{tabular}{|c|c|c|c|c|c|c|c|c|c|c|c|c|c|c|c|c|c|c|c|}
\hline \multicolumn{20}{|c|}{ Apatite (U-Th)/He analysis } \\
\hline Sample & Crystal & u & Th & Sm & $\mathrm{He}$ & $\mathrm{eU}$ & Term. & Radius & Age Unc. & $\pm 1 \sigma$ & Ave. Unc. & SD & $\pm 1 \sigma$ & $\mathrm{Ft}$ & Age Corr. & \pm 10 & Ave. Corr. & SD & $\pm 1 \sigma$ \\
\hline$\#$ & \# & $(\mathrm{ppm})$ & (ppm) & $(\mathrm{ppm})$ & $(\mathrm{nmol} / \mathrm{g})$ & $(\mathrm{ppm})$ & \# & $(\mu \mathrm{m})$ & (Ma) & (Ma) & (Ma) & (Ma) & (Ma) & \# & (Ma) & (Ma) & (Ma) & (Ma) & (Ma) \\
\hline \multicolumn{20}{|c|}{ Cuchilla Dionisio Terrane } \\
\hline \multirow[t]{3}{*}{ UY2 } & 1 & 59.92 & 130.15 & 488.89 & 146.82 & 92.67 & 1 & 57.38 & 292.10 & 5.96 & 441.09 & 106.69 & 61.60 & 0.74 & 392.38 & 8.07 & 546.46 & 109.62 & 63.29 \\
\hline & 2 & 21.79 & 61.86 & 368.63 & 101.75 & 37.99 & 1 & 79.51 & 494.97 & 10.11 & & & & 0.81 & 608.67 & 12.54 & & & \\
\hline & 3 & 8.78 & 24.84 & 305.88 & 45.05 & 16.03 & 2 & 92.53 & 536.20 & 11.07 & & & & 0.84 & 638.33 & 13.27 & & & \\
\hline \multirow[t]{3}{*}{ UY30 } & 1 & 8.13 & 12.82 & 214.17 & 7.49 & 12.14 & 2 & 42.71 & 120.51 & 2.68 & 107.98 & 10.71 & 6.18 & 0.67 & 180.31 & 4.03 & 152.31 & 21.71 & 12.53 \\
\hline & 2 & 24.29 & 19.84 & 478.29 & 15.14 & 31.18 & 2 & 55.35 & 94.34 & 1.31 & & & & 0.74 & 127.41 & 1.77 & & & \\
\hline & 3 & 9.85 & 8.15 & 18.56 & 7.00 & 11.85 & 1 & 53.89 & 109.09 & 1.69 & & & & 0.73 & 149.21 & 2.33 & & & \\
\hline \multirow[t]{3}{*}{ UY32 } & 1 & 59.86 & 11.48 & 467.66 & 38.88 & 64.74 & 2 & 40.45 & 113.17 & 2.51 & 135.58 & 50.08 & 28.91 & 0.66 & 171.81 & 3.83 & 196.36 & 69.34 & 40.03 \\
\hline & 2 & 45.55 & 5.08 & 421.35 & 22.73 & 48.72 & 1 & 46.78 & 88.60 & 1.97 & & & & 0.70 & 126.41 & 2.83 & & & \\
\hline & 3 & 46.53 & 4.36 & 447.24 & 54.10 & 49.65 & 1 & 46.86 & 204.97 & 4.58 & & & & 0.70 & 290.85 & 6.54 & & & \\
\hline \multirow[t]{2}{*}{ UY24 } & 1 & 3.91 & 2.21 & 271.49 & 4.03 & 5.70 & 1 & 45.94 & 155.03 & 4.61 & 211.19 & 56.16 & 39.71 & 0.71 & 219.65 & 6.55 & 314.97 & 95.32 & 67.40 \\
\hline & 2 & 2.22 & 1.89 & 469.70 & 4.75 & 4.87 & 1 & 34.84 & 267.35 & 10.79 & & & & 0.65 & 410.29 & 16.33 & & & \\
\hline \multicolumn{20}{|c|}{ Nico Pérez Terrane } \\
\hline \multirow[t]{3}{*}{ UY1 } & 3 & 14.64 & 2.24 & 157.52 & 8.04 & 15.90 & 1 & 62.41 & 96.34 & 2.15 & 131.16 & 29.66 & 17.13 & 0.77 & 125.01 & 2.80 & 170.41 & 32.60 & 18.82 \\
\hline & 4 & 19.69 & 54.24 & 222.63 & 22.89 & 33.42 & 1 & 47.23 & 128.32 & 1.81 & & & & 0.69 & 186.17 & 2.65 & & & \\
\hline & 5 & 26.26 & 25.87 & 124.55 & 30.01 & 32.90 & 2 & 95.87 & 168.83 & 2.52 & & & & 0.84 & 200.06 & 3.00 & & & \\
\hline \multirow[t]{3}{*}{ UY6 } & 1 & 7.99 & 36.96 & 66.71 & 15.38 & 16.96 & 2 & 66.62 & 167.83 & 3.39 & 262.62 & 67.12 & 38.75 & 0.77 & 218.10 & 4.42 & 346.05 & 90.48 & 52.24 \\
\hline & 2 & 9.03 & 43.73 & 74.69 & 32.68 & 19.61 & 2 & 59.49 & 305.66 & 6.20 & & & & 0.75 & 409.89 & 8.37 & & & \\
\hline & 3 & 5.90 & 24.48 & 68.68 & 20.36 & 11.95 & 2 & 64.67 & 314.37 & 6.41 & & & & 0.77 & 410.17 & 8.42 & & & \\
\hline \multirow[t]{4}{*}{ UY8 } & 1 & 4.54 & 15.55 & 44.52 & 7.53 & 8.39 & 1 & 47.93 & 166.91 & 2.27 & 182.64 & 40.46 & 18.09 & 0.69 & 241.31 & 3.32 & 281.44 & 63.42 & 28.36 \\
\hline & 2 & 21.50 & 41.04 & 72.27 & 21.49 & 31.45 & 2 & 38.08 & 126.17 & 1.46 & & & & 0.63 & 201.46 & 2.37 & & & \\
\hline & 3 & 11.28 & 50.36 & 358.19 & 30.32 & 24.75 & 2 & 41.09 & 234.61 & 3.28 & & & & 0.65 & 362.35 & 5.08 & & & \\
\hline & 4 & 11.46 & 44.23 & 88.01 & 24.41 & 22.22 & 1 & 39.51 & 202.88 & 2.86 & & & & 0.63 & 320.65 & 4.56 & & & \\
\hline \multirow[t]{3}{*}{ UY11 } & 1 & 4.25 & 36.85 & 694.43 & 20.01 & 16.14 & 2 & 52.86 & 265.25 & 3.24 & 208.62 & 48.20 & 27.83 & 0.72 & 367.60 & 4.44 & 285.99 & 61.74 & 35.65 \\
\hline & 2 & 6.21 & 43.76 & 359.92 & 13.63 & 18.14 & 1 & 45.83 & 147.43 & 1.89 & & & & 0.68 & 218.29 & 2.79 & & & \\
\hline & 3 & 8.34 & 74.17 & 621.66 & 30.96 & 28.61 & 1 & 71.44 & 213.17 & 2.59 & & & & 0.78 & 272.07 & 3.29 & & & \\
\hline \multirow[t]{4}{*}{ UY14 } & 1 & 3.10 & 23.24 & 96.80 & 4.47 & 9.00 & 2 & 73.47 & 94.61 & 1.22 & 103.01 & 16.33 & 7.30 & 0.79 & 120.26 & 1.55 & 133.43 & 20.82 & 9.31 \\
\hline & 2 & 3.92 & 24.81 & 91.44 & 6.31 & 10.16 & 2 & 62.63 & 117.32 & 1.33 & & & & 0.75 & 155.65 & 1.76 & & & \\
\hline & 3 & 5.86 & 22.81 & 69.82 & 4.94 & 11.53 & 2 & 62.61 & 80.37 & 0.90 & & & & 0.76 & 106.26 & 1.19 & & & \\
\hline & 5 & 2.84 & 20.74 & 85.27 & 5.10 & 8.09 & 2 & 74.51 & 119.73 & 1.42 & & & & 0.79 & 151.57 & 1.79 & & & \\
\hline \multirow[t]{2}{*}{ UY21 } & 1 & 18.58 & 52.98 & 716.38 & 15.92 & 97.71 & 1 & 41.89 & 91.78 & 1.90 & 105.94 & 14.16 & 8.18 & 0.68 & 139.63 & 2.90 & 152.94 & 13.31 & 7.69 \\
\hline & 3 & 9.90 & 20.42 & 218.52 & 9.79 & 16.23 & 2 & 52.63 & 120.10 & 2.57 & & & & 0.71 & 166.25 & 3.58 & & & \\
\hline \multicolumn{20}{|c|}{ Piedra Alta Terrane } \\
\hline \multirow[t]{3}{*}{ UY16 } & 1 & 6.08 & 24.39 & 164.32 & 14.82 & 12.56 & 2 & 54.18 & 224.94 & 2.63 & 250.26 & 18.01 & 10.40 & 0.73 & 310.02 & 3.64 & 328.44 & 23.04 & 13.30 \\
\hline & 2 & 8.40 & 23.61 & 171.26 & 20.68 & 14.73 & 2 & 55.50 & 265.35 & 2.98 & & & & 0.74 & 360.93 & 4.09 & & & \\
\hline & 3 & 10.39 & 8.93 & 103.22 & 18.10 & 12.96 & 2 & 85.64 & 260.49 & 3.26 & & & & 0.83 & 314.37 & 3.96 & & & \\
\hline UY25 & 1 & 56.87 & 38.42 & 271.62 & 64.15 & 67.13 & 1 & 49.97 & 176.95 & 3.78 & 258.83 & 59.84 & 34.55 & 0.72 & 247.45 & 5.32 & 368.18 & 85.42 & 49.32 \\
\hline & 2 & 25.50 & 24.77 & 219.10 & 55.67 & 32.33 & 1 & 56.98 & 318.28 & 6.78 & & & & 0.75 & 424.81 & 9.15 & & & \\
\hline & 3 & 27.21 & 24.40 & 212.86 & 51.57 & 33.92 & 2 & 39.58 & 281.27 & 6.07 & & & & 0.65 & 432.29 & 9.47 & & & \\
\hline UY27 & 1 & 13.43 & 16.16 & 314.13 & 30.29 & 18.69 & 2 & 46.35 & 311.03 & 3.97 & 263.80 & 34.10 & 19.69 & 0.70 & 445.54 & 5.76 & 388.25 & 40.51 & 23.39 \\
\hline & 2 & 23.25 & 42.01 & 431.60 & 42.83 & 35.11 & 2 & 39.54 & 231.74 & 2.76 & & & & 0.64 & 359.42 & 4.34 & & & \\
\hline & 3 & 19.50 & 36.16 & 468.71 & 39.06 & 30.16 & 2 & 46.06 & 248.63 & 2.92 & & & & 0.69 & 359.80 & 4.27 & & & \\
\hline Tandilia T & rrane & & & & & & & & & & & & & & & & & & \\
\hline UY18 & 1 & 9.44 & 2.74 & 129.44 & 12.50 & 10.69 & 2 & 49.67 & 222.16 & 6.50 & 201.68 & 21.16 & 10.58 & 0.72 & 308.79 & 9.10 & 289.96 & 34.86 & 17.43 \\
\hline & 2 & 16.26 & 12.18 & 136.90 & 18.21 & 19.75 & 2 & 50.06 & 172.54 & 3.98 & & & & 0.72 & 241.10 & 5.60 & & & \\
\hline 5 & 3 & 12.28 & 4.32 & 108.17 & 15.50 & 13.79 & 2 & 40.05 & 210.33 & 5.11 & & & & 0.66 & 320.01 & 7.86 & & & \\
\hline
\end{tabular}

Table 3: Summary of Apatite (U-Th)/He ages and parameters. Crystal dimensions were

558 crystal terminations; Unc., uncorrected; Corr., corrected; SD, standard deviation; Ft, alpha

$559 \quad$ ejection factor for age correction.

560 5.3 Zircon (U-Th)/He

561 A total of 40 zircons were dated from eight locations across the UYS (Tab. 4). Single

562 crystal ZHe ages range through the entire Paleozoic and show a strong negative correlation

563 with eU, unlike our AHe ages (Fig. 6). Such negative correlation is common in cratonic

564 regions and usually is attributed to long-term accumulation of radiation damage in the

565 crystals. Zircons with high eU and long low-temperature histories are prone to develop a 
566 damage net within the crystalline lattice, which increases the diffusivity and loss of alpha

567 particles, thus resulting in younger ages (Reiners 2005; Guenthner et al. 2013). Considering

568 this, we opted to show in the map (Fig. 2) the oldest single grain ZHe age for each location,

569 usually Cambrian/Ordovician for the NPT and CDT samples, and Permian for the PAT. The

570 oldest $\mathrm{ZHe}$ age potentially represents the cooling age of the least damaged zircon analyzed,

571 likely closer to the beginning of the ${ }^{4} \mathrm{He}$ accumulation within the sample and to the standard

572 closure temperature of the ZHe system. No correlation between ZHe ages and crystal radius,

573 location or altitude was observed in our samples.

574
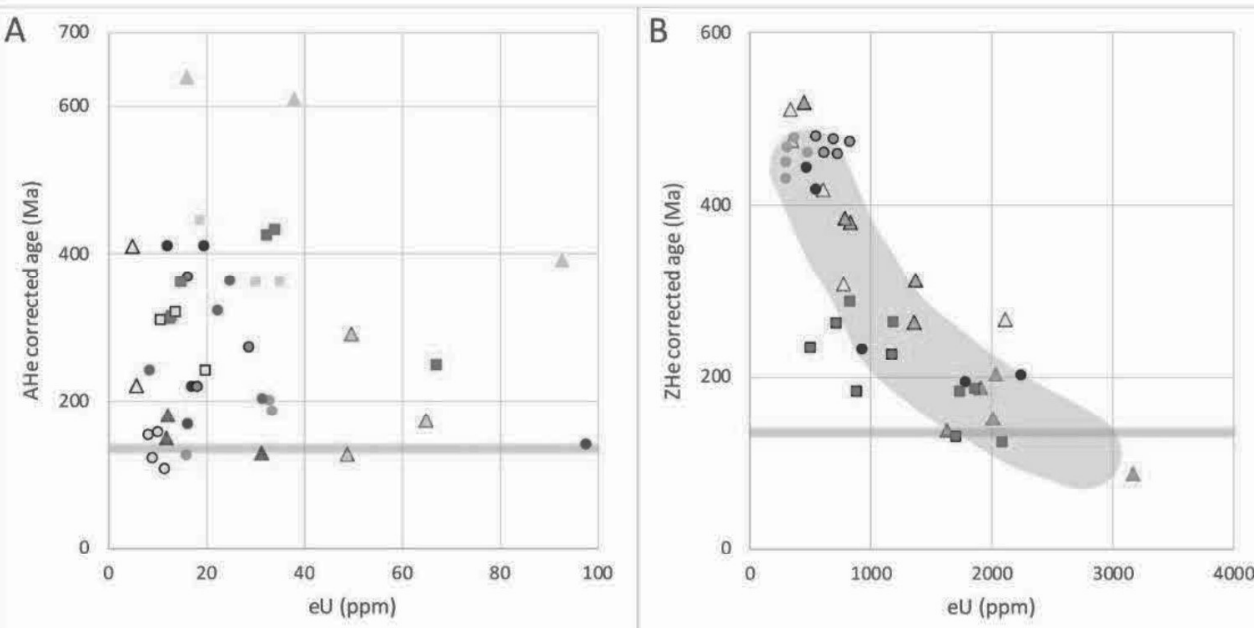

Cuchilla Dionisio Terrane $\triangle$ UY2 $\triangle$ UY24 $\triangle$ UY30 $\triangle$ UY32

Piedra Alta Terrane =UY16 a UY18 $=$ UY25 $=$ UY27

Nico Pérez Terrane $\quad$ UY1 • UY6 • UY8 ๑ UY11 ० UY14 • UY21

Cuchilla Dionisio Terrane $\triangle$ UY2 $\triangle$ UY29 $\triangle$ UY32

Piedra Alta Terrane a UY27ø UY18

Nico Pérez Terrane - UY8 $\bullet$ UY10 o UY13

Figure 6. Plots of $(\mathrm{U}-\mathrm{Th} / \mathrm{He})$ corrected ages against effective uranium content $(\mathrm{e} U=[\mathrm{U}]+0.235 \times$

A) AHe ages showing variable intrasample behavior and no apparent general trend. (B) ZHe ages

578 clustered or showing a negative correlation intrasample and as general trend. Horizontal bar indicates the

579 Paraná-Etendeka LIP volcanism. 


\begin{tabular}{|c|c|c|c|c|c|c|c|c|c|c|c|c|c|c|c|c|c|}
\hline \multicolumn{18}{|c|}{ Zircon (U-Th)/He analysis } \\
\hline Sample & Crystal & U & Th & $\mathrm{He}$ & $\mathrm{eU}$ & Radius & Age Unc. & $\pm 1 \sigma$ & Ave. Unc. & SD & $\pm 1 \sigma$ & $\mathrm{Ft}$ & Age Corr & $\pm 1 \sigma$ & Ave. Corr. & SD & $\pm 1 \sigma$ \\
\hline \# & \# & $(\mathrm{ppm})$ & $(\mathrm{ppm})$ & $(\mathrm{nmol} / \mathrm{g})$ & (ppm) & $(\mu \mathrm{m})$ & (Ma) & (Ma) & (Ma) & (Ma) & (Ma) & \# & (Ma) & (Ma) & (Ma) & (Ma) & (Ma) \\
\hline \multicolumn{18}{|c|}{ Cuchilla Dionisio Terrane } \\
\hline \multirow[t]{5}{*}{ UY2 } & 1 & 1216.02 & 636.19 & 1592.79 & 1365.52 & 36.94 & 212.40 & 3.02 & 273.11 & 68.31 & 30.55 & 0.68 & 311.46 & 4.49 & 371.45 & 86.13 & 38.52 \\
\hline & 2 & 773.03 & 215.67 & 1214.88 & 823.71 & 39.61 & 267.17 & 5.04 & & & & 0.70 & 379.04 & 7.24 & & & \\
\hline & 3 & 741.36 & 175.63 & 1292.37 & 782.64 & 52.87 & 298.24 & 5.68 & & & & 0.77 & 385.10 & 7.41 & & & \\
\hline & 4 & 395.44 & 195.09 & 957.90 & 441.28 & 47.41 & 389.04 & 7.28 & & & & 0.75 & 518.30 & 9.84 & & & \\
\hline & 7 & 1267.26 & 388.53 & 1480.69 & 1358.56 & 48.81 & 198.68 & 3.71 & & & & 0.75 & 263.37 & 4.96 & & & \\
\hline \multirow[t]{5}{*}{ UY29 } & 1 & 543.50 & 270.19 & 1130.77 & 606.99 & 61.94 & 335.50 & 4.39 & 299.50 & 80.16 & 35.85 & 0.80 & 417.01 & 5.52 & 395.12 & 94.15 & 42.11 \\
\hline & 2 & 293.29 & 213.03 & 693.26 & 343.35 & 50.85 & 362.95 & 4.57 & & & & 0.76 & 475.00 & 6.09 & & & \\
\hline & 3 & 1963.03 & 622.64 & 2228.84 & 2109.35 & 42.73 & 192.73 & 2.84 & & & & 0.72 & 266.84 & 3.97 & & & \\
\hline & 4 & 298.36 & 167.44 & 736.46 & 337.71 & 50.99 & 390.86 & 5.61 & & & & 0.77 & 509.99 & 7.43 & & & \\
\hline & 5 & 704.82 & 281.30 & 912.64 & 770.93 & 39.63 & 215.49 & 3.13 & & & & 0.70 & 306.73 & 4.52 & & & \\
\hline \multirow[t]{5}{*}{ UY32 } & 1 & 2844.44 & 1344.08 & 1280.10 & 3160.30 & 94.20 & 74.66 & 1.03 & 121.47 & 29.46 & 13.18 & 0.87 & 86.22 & 1.20 & 152.75 & 40.98 & 18.33 \\
\hline & 2 & 1943.91 & 245.54 & 1307.62 & 2001.62 & 59.78 & 119.95 & 1.73 & & & & 0.80 & 150.63 & 2.18 & & & \\
\hline & 3 & 1857.49 & 725.71 & 1768.94 & 2028.03 & 57.63 & 159.57 & 2.22 & & & & 0.79 & 202.44 & 2.83 & & & \\
\hline & 4 & 1138.28 & 3274.83 & 1505.60 & 1907.87 & 55.28 & 144.52 & 1.60 & & & & 0.77 & 187.89 & 2.09 & & & \\
\hline & 5 & 1542.94 & 344.60 & 960.09 & 1623.92 & 59.83 & 108.67 & 1.50 & & & & 0.80 & 136.58 & 1.90 & & & \\
\hline \multicolumn{18}{|c|}{ Nico Pérez Terrane } \\
\hline \multirow[t]{5}{*}{ UY8 } & 1 & 438.83 & 158.79 & 1033.20 & 476.15 & 77.94 & 388.74 & 6.15 & 377.98 & 21.07 & 9.42 & 0.84 & 460.49 & 7.35 & 456.99 & 16.15 & 7.22 \\
\hline & 2 & 281.82 & 94.67 & 569.75 & 304.06 & 55.21 & 337.27 & 5.32 & & & & 0.78 & 430.51 & 6.87 & & & \\
\hline & 3 & 280.84 & 77.47 & 647.22 & 299.04 & 88.50 & 387.67 & 6.27 & & & & 0.86 & 449.53 & 7.32 & & & \\
\hline & 4 & 350.88 & 76.05 & 817.60 & 368.75 & 70.52 & 396.72 & 5.74 & & & & 0.83 & 478.21 & 6.98 & & & \\
\hline & 5 & 281.90 & 113.49 & 653.05 & 308.57 & 64.82 & 379.52 & 5.32 & & & & 0.81 & 466.22 & 6.61 & & & \\
\hline \multirow[t]{5}{*}{ UY10 } & 2 & 1519.54 & 1104.20 & 1203.76 & 1779.03 & 32.76 & 124.16 & 1.53 & 213.19 & 89.58 & 40.06 & 0.64 & 193.48 & 2.43 & 297.42 & 109.43 & 48.94 \\
\hline & 3 & 1821.40 & 1769.65 & 1672.24 & 2237.27 & 37.42 & 137.00 & 1.65 & & & & 0.68 & 201.41 & 2.47 & & & \\
\hline & 4 & 758.05 & 703.75 & 812.20 & 923.43 & 39.14 & 160.89 & 1.98 & & & & 0.69 & 231.92 & 2.90 & & & \\
\hline & 6 & 415.63 & 219.89 & 836.49 & 467.30 & 43.53 & 322.77 & 5.21 & & & & 0.73 & 443.12 & 7.25 & & & \\
\hline & 7 & 489.04 & 235.10 & 969.29 & 544.29 & 52.03 & 321.12 & 5.19 & & & & 0.77 & 417.14 & 6.82 & & & \\
\hline \multirow[t]{5}{*}{ UY13 } & 1 & 646.57 & 326.51 & 1441.94 & 723.30 & 54.84 & 358.30 & 6.20 & 365.08 & 12.08 & 5.40 & 0.78 & 458.57 & 8.03 & 469.36 & 8.45 & 3.78 \\
\hline & 2 & 628.19 & 257.97 & 1467.16 & 688.81 & 60.34 & 381.89 & 6.69 & & & & 0.80 & 476.73 & 8.45 & & & \\
\hline & 3 & 491.98 & 235.19 & 1140.75 & 547.25 & 54.63 & 374.08 & 6.54 & & & & 0.78 & 478.93 & 8.48 & & & \\
\hline & 4 & 770.65 & 247.05 & 1600.27 & 828.70 & 44.30 & 347.24 & 5.86 & & & & 0.73 & 472.45 & 8.09 & & & \\
\hline & 5 & 560.25 & 224.84 & 1242.32 & 613.09 & 57.29 & 363.90 & 6.07 & & & & 0.79 & 460.11 & 7.76 & & & \\
\hline \multicolumn{18}{|c|}{ Piedra Alta Terrane } \\
\hline \multirow[t]{5}{*}{ UY27 } & 1 & 851.37 & 116.24 & 755.00 & 878.69 & 90.84 & 157.22 & 2.19 & 170.76 & 40.11 & 17.94 & 0.86 & 182.07 & 2.54 & 206.24 & 46.65 & 20.86 \\
\hline & 2 & 1102.95 & 316.03 & 1163.28 & 1177.22 & 60.71 & 180.43 & 2.46 & & & & 0.80 & 225.73 & 3.10 & & & \\
\hline & 3 & 1629.90 & 301.28 & 945.84 & 1700.71 & 60.34 & 102.28 & 1.44 & & & & 0.80 & 128.27 & 1.81 & & & \\
\hline & 4 & 483.89 & 69.39 & 525.97 & 500.19 & 68.89 & 191.79 & 3.14 & & & & 0.82 & 233.07 & 3.84 & & & \\
\hline & 5 & 670.02 & 204.32 & 876.64 & 718.04 & 80.79 & 222.08 & 3.49 & & & & 0.85 & 262.08 & 4.14 & & & \\
\hline \multicolumn{18}{|c|}{ Tandilia Terrane } \\
\hline \multirow[t]{4}{*}{ UY18 } & 1 & 2012.46 & 328.91 & 1106.92 & 2089.76 & 59.72 & 97.46 & 1.61 & 154.81 & 42.01 & 18.79 & 0.80 & 122.52 & 2.03 & 207.89 & 59.07 & 26.42 \\
\hline & 2 & 1670.14 & 299.44 & 1299.07 & 1740.51 & 47.60 & 136.83 & 1.86 & & & & 0.75 & 182.88 & 2.51 & & & \\
\hline & 4 & 1771.17 & 383.20 & 1365.69 & 1861.22 & 43.11 & 134.55 & 1.81 & & & & 0.72 & 185.87 & 2.52 & & & \\
\hline & 5 & 1105.25 & 334.62 & 1245.33 & 1183.88 & 44.39 & 191.87 & 2.58 & & & & 0.73 & 262.18 & 3.56 & & & \\
\hline 30 & 6 & 784.68 & 167.61 & 965.85 & 824.07 & 46.85 & 213.35 & 3.77 & & & & 0.75 & 286.00 & 5.10 & & & \\
\hline
\end{tabular}

585 The thermal history of 19 locations was computed by inverse modeling and the results

586 can be divided into two main groups with distinct cooling patterns. All models use AFT data

587 as baseline, thermochronometer with the most consistent regional results and those physical

588 proprieties that are better understood in the scientific community, but most of the models

589 include (U-Th)/He data as well. Final models display a good fit between observed and 
591 Representative models are shown in Figure 7 and the final models of each sample can be

592 found in the Supplementary Material.

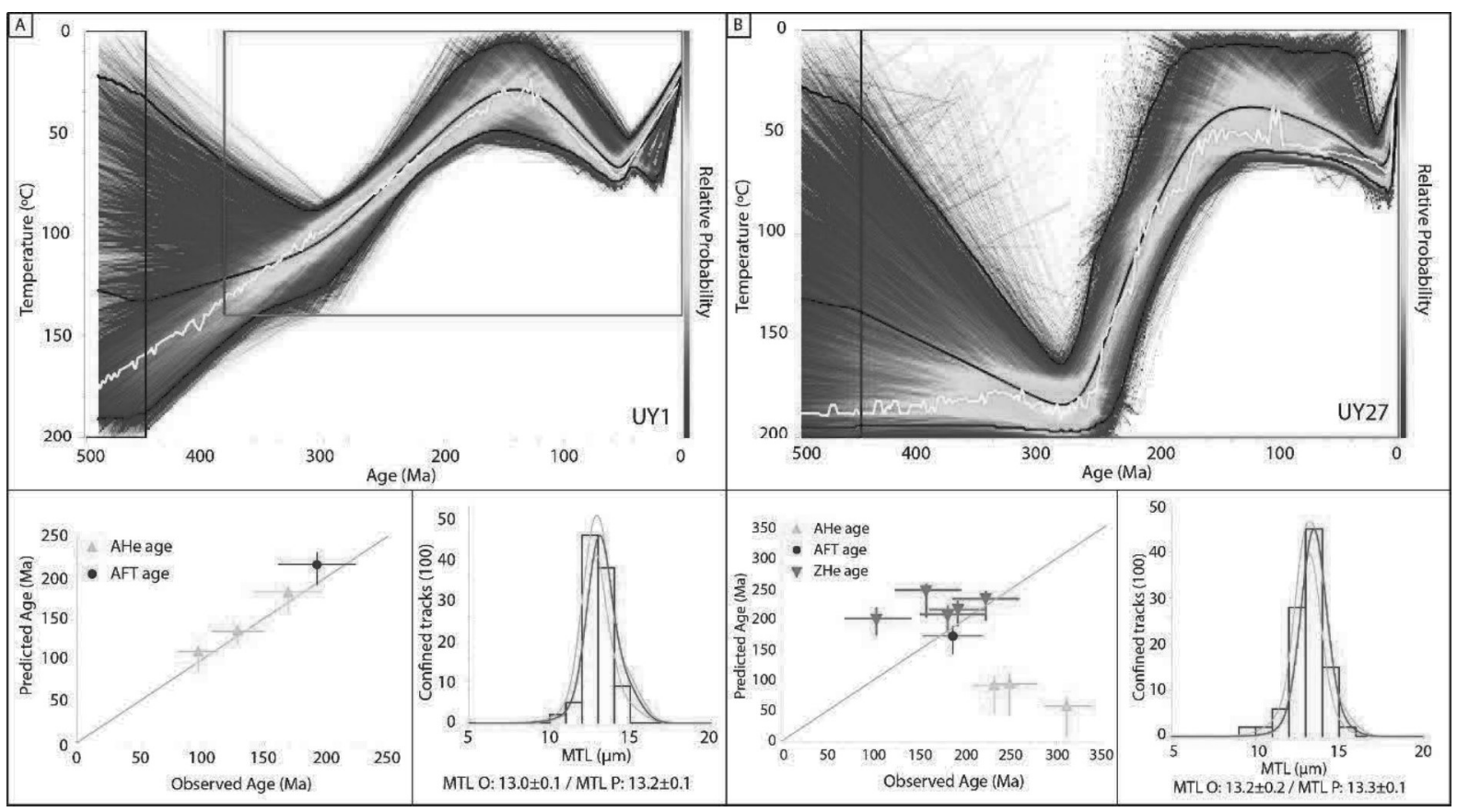

Figure 7. Panel of representative inverse thermal models from Group 1. (A) On the top: Model for sample UY1. Black line represents the mean cooling trajectory, white line the maximum mode and colored pathway the $95 \%$ confidence interval with relative probability scale. Black rectangle is the start constraint box for the model, red box the prior to test thermal paths (see Gallagher, 2012). Bottom left: fit between observed ages and predicted ages by the model, including $\pm 1 \sigma$ range. Bottom right: track length distribution with values of MTL observed and predicted by the model. (B): Same as in (A) but for sample UY27, with ZHe data.

Group 1 is composed of samples UY1, UY2, UY6, UY7, UY8, UY16, UY18, UY25, part of the NPT). Models from these samples show passage through the AFTPRZ between $c$. 300 and $180 \mathrm{Ma}$ (Fig. 8), with cooling rates varying between 0.60 and $0.32{ }^{\circ} \mathrm{C} / \mathrm{Ma}$. In most cases, entrance in the AFTPRZ $\left(\right.$ c. $\left.110^{\circ} \mathrm{C}\right)$ occurs in the Carboniferous-Permian transition, while cooling out from the zone $\left(c .60^{\circ} \mathrm{C}\right)$ occurs by Late Jurassic-Early Jurassic. Samples UY18 and UY27, which present relatively young ZHe ages, went through the AFTPRZ slightly later and faster $\left(\right.$ c. $\left.0.90{ }^{\circ} \mathrm{C} / \mathrm{Ma}\right)$ than the general trend. Models from Group 1 suggest that in Early Cretaceous all these samples might have reached surface temperatures, although it cannot be precisely constrained by our AHe data (Fig. 7). Afterwards, all models support a 
610 subtle reheating phase, that possibly lasted until the end of the Paleogene and raised

611 temperatures slightly over $60{ }^{\circ} \mathrm{C}$ in some samples. This reheating is at the limit of the AFT

612 method resolution, and possibly a modeling artifact (Jonckheere 2003), a reflection of the

613 considerably short length of the confined tracks of these samples, usually below $12 \mu \mathrm{m}$,

614 which would require a prolonged time in the AFTPRZ. A final cooling towards surface

615 temperature takes place by the Miocene. Sample UY29 resulted in a thermal history similar

616 to Group 1 but with earlier and faster passage through the AFTPRZ, at a rate of $0.88^{\circ} \mathrm{C} / \mathrm{Ma}$.

617 Cooling into the AFTPRZ occurs by the Devonian-Carboniferous transition with an exit by

618 the Permian. The model from this sample shows stability at temperatures around 30 to $50{ }^{\circ} \mathrm{C}$

619 until the Cretaceous, when a reheating phase occurred raising the temperature to $75^{\circ} \mathrm{C}$. A

620 final cooling towards surface conditions is observed after the Paleocene. Sample UY29 is

621 located in the extreme SE of the shield, where most samples present thermal histories

622 belonging to Group 2.

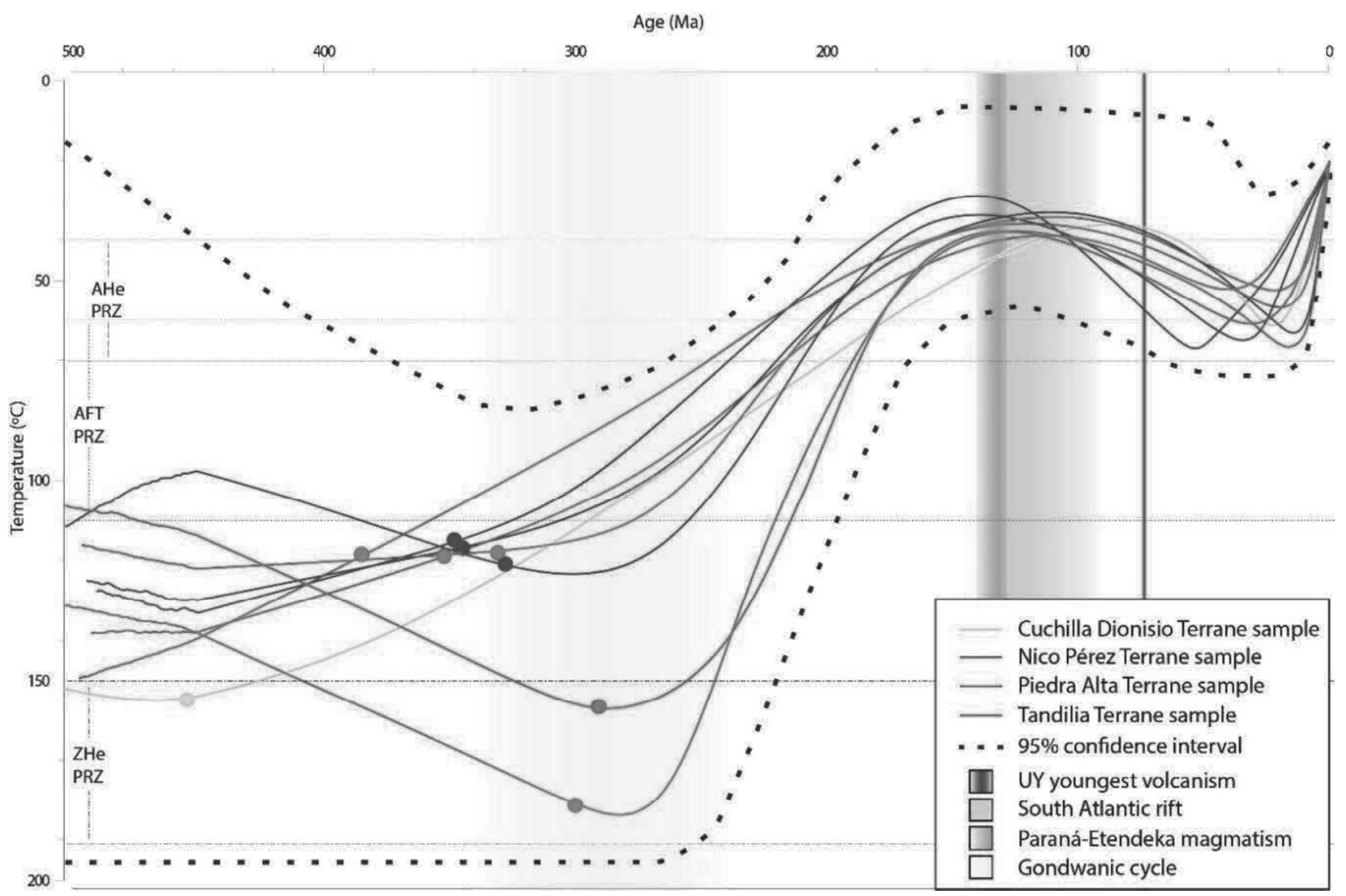

Figure 8. Mean cooling trajectories of inverse models for samples from Group 1. Dashed bold lines 
trajectory relative probability is over $50 \%$ inside the confidence interval. i.e. model curve before the dot is

627 poorly constrained. Approximate interval of $P R Z$ of each thermochronometer indicated with dashed horizontal

628 lines. Main thermotectonic events in the region are indicated as shaded bars: Gondwanic cycle (c. 340 to 250

629 Ma) (Milani \& De Wit, 2014), Paraná-Etendeka LIP (138 to 125 Ma) (Rossetti et al. 2014) and Atlantic Ocean

630 opening (130 to 113 Ma) (Stica et al. 2014).

632 and UY32. These samples are located mostly in the center and SE of the shield (NPT and

633 CDT), and are often near shear zones. Unlike Group 1, the models for these samples lack a

634 Late Cretaceous reheating phase, and show a monotonic cooling towards surface since early

635 Mesozoic. The time of cooling into the AFTPRZ occurs later than Group 1 and is variable

636 among the samples, ranging between the Permian and Jurassic. Cooling occurs at rates

637 between 0.30 and $0.71{ }^{\circ} \mathrm{C} / \mathrm{Ma}$, and during the Cretaceous all samples reached temperatures

638 below $60^{\circ} \mathrm{C}$. Although Group 2 corresponds to protracted and monotonic thermal histories, it

639 should be considered that some of these samples have a limited number $(<50)$ of confined

640 tracks to be used during modeling, thus their models are less robust. Nonetheless, all of them

641 have younger AFT ages and higher track length values (MTL) than Group 1, with lengths

642 usually above $12.2 \mu \mathrm{m}$, even when 100 confined tracks were measured. Therefore, their

643 monotonic thermal histories can represent Mesozoic tectonic activity in faults/shear zones or

644 at the margins of the shield, especially near the Atlantic Ocean, but can also reflect their long

645 and often limited number of confined tracks, which do not require a protracted period in the

646 AFTPRZ or a reheating phase to shorten them as in Group 1. 


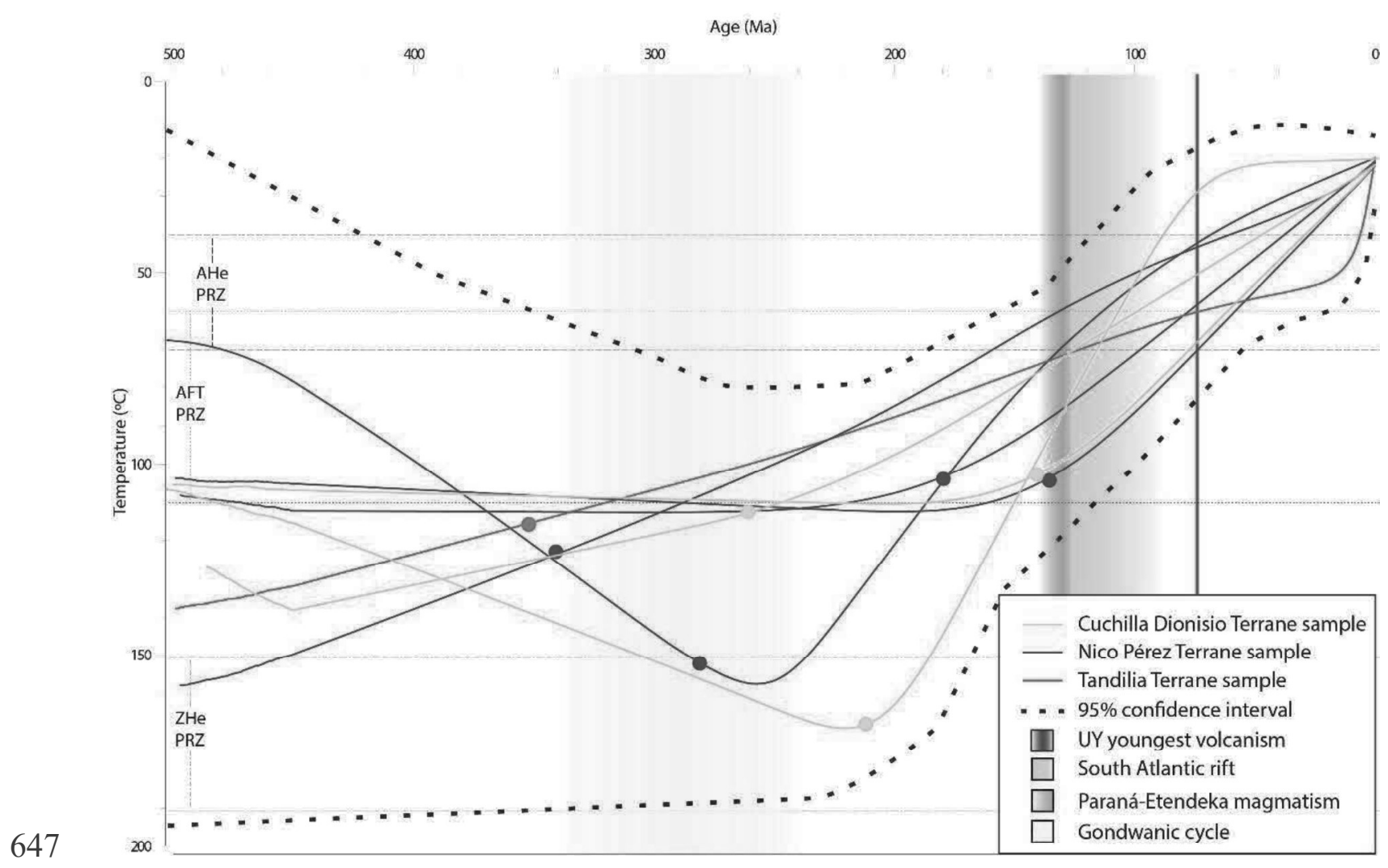

Figure 9. Mean cooling trajectories of inverse models for samples from Group 2. Dashed bold lines represent the superposition of the $95 \%$ confidence interval of individual models. Dots indicate point after which trajectory relative probability is over $50 \%$ inside the confidence interval. i.e. model curve before the dot is poorly constrained. Approximate interval of PRZ of each thermochronometer indicated with dashed horizontal lines. Main thermotectonic events in the region are indicated as shaded bars: Gondwanic cycle (c. 340 to 250 Ma) (Milani \& De Wit, 2014), Paraná-Etendeka LIP (138 to 125 Ma) (Rossetti et al. 2014) and Atlantic Ocean opening (130 to $113 \mathrm{Ma}$ ) (Stica et al. 2014).

661 the integration of these data, we characterized the thermal evolution of the shield during the

662 Phanerozoic and discuss the exhumation of the basement, taking into account the apparent disparities between previous models. 
All AFT ages obtained in this work are much younger than the host rock stratigraphic age and the last orogenic cycle that affected the region (Gondwana assembly during the

667 Brasiliano/Pan-African cycle, late Neoproterozoic-Cambrian). Thus, we interpret our AFT ages as cooling ages that represent exhumation of the basement due to denudational events. There is good agreement between our AFT ages and those obtained by Kollenz (2015) and Gomes \& Almeida (2018), totaling a combined dataset of 36 AFT ages across the UYS. Although the shield does not have significant topographic variations, a plot of the AFT central ages against sample elevation, including the works aforementioned, presents clear positive correlations for the CDT, NPT and PAT (Fig. 3). Ages also tend to increase with the distance from the South Atlantic Ocean, a common pattern observed in continental passive margins (Gallagher \& Brown 1997). The PAT, representative of the Rio de La Plata Craton, and the northern part of the NPT, arguably part of the craton as well, concentrates the older AFT ages in Uruguay. Remarkable is the similarity between the confined track lengths in the three works, both in values and distributions, which reveal MTL of short to medium values, independently of the location in the shield. This pattern of tracks with reduced lengths implies that the samples went through a long period at temperatures close or inside the AFTPRZ, allowing continuous annealing of the tracks. The medium-high $\mathrm{D}_{\text {par }}$ values of our samples, indicative of fairly high resistance to annealing (Carlson et al. 1999; Donelick et al. 2005), reinforce this interpretation. higher dispersion when compared to those obtained by Hueck et al. (2017), who reported mainly Permian to mid-Cretaceous ages, but discarded several older crystals. Although the

687 AHe represents a lower temperature thermochronometer than the AFT system, our AHe ages are usually older than AFT ages from the same sample, in an inverse pattern common in 
cratonic regions (Flowers \& Kelley 2011). This inverted behavior is characteristic for apatites

with eU $>15$ ppm subject to prolonged residence at temperatures below $70{ }^{\circ} \mathrm{C}$, and

691 augmented by reheating episodes that do not reset the AHe ages (Shuster et al. 2006; Reiners

692 et al. 2018). The wide dispersion of AHe ages within a sample can be attributed to internal

693 factors, such as chemical zonation and alpha implantation, among others, that affect single

694 aliquots. However, because inversion of AHe and AFT ages is a pattern in our dataset, and considerable dispersion of AHe ages is observed in almost every sample, this behavior must be attributed to a more embracing mechanism. Considering that our samples are of

697 Precambrian rocks, and that our models and AFT data indicate residence at low temperatures

$698\left(<110^{\circ} \mathrm{C}\right)$ since the middle Mesozoic, it is likely that the analyzed apatites have accumulated 699 a relatively high degree of radiation in the last $200 \mathrm{Ma}$. The damaged crystal lattice affects the diffusivity of the alpha particles within the apatites, initially increasing the retentivity of

$701 \mathrm{He}$, and resulting in abnormally old ages for the AHe system (Green \& Duddy 2006; Shuster et al. 2006). Furthermore, Shuster et al. (2006) claims that apatite with variable eU content and subject to a reheating episode after significant accumulation of radiation damage might present a large span of $\mathrm{AHe}$ ages, being most extreme when the reheating increase temperatures close to $60{ }^{\circ} \mathrm{C}$. Therefore, it is likely that some of our AHe ages are affected by intrasample factors, but it is plausible that the general behavior observed in the UYS is a consequence of accumulation of radiation damage in the apatites since the early Mesozoic, with dispersion augmented by an episode of subtle reheat in the region. The accumulation of radiation damage plays a major role in our $\mathrm{ZHe}$ ages as well. If the density of damage sites overcome a threshold, they can become interconnected and

711 decrease the retentivity of He, resulting in young ages owing to rapid He escape. Because a

712 zircon's eU is usually one or two orders of magnitude higher than an apatite's eU, the

713 connection between radioactive defects within the crystal lattice after long-term residence at 
714 shallow temperatures is very likely. Therefore, although our ZHe ages tend to be younger

715 than the ones obtained by Hueck et al. (2017), this can be attributed to the difference in the

$716 \mathrm{eU}$ of the zircons analyzed in each work. While we found that our dispersed ages have a clear

717 negative correlation with eU, which varies between 299 and 3160 ppm (Fig. 6), Hueck et al.

718 (2017) presented mostly zircons with eU below 500 ppm and whose ZHe ages clustered in

719 the Cambrian. Our low eU samples present very similar ages to those from their work,

720 indicating that most of the UYS reached temperatures within the ZHePRZ in the early

721 Paleozoic. Additionally, the age dispersion observed by us indicates that samples passed

722 through a protracted period of low temperatures $\left(<150^{\circ} \mathrm{C}\right)$, favoring the accumulation of

723 radiation damage that when interconnected became escape paths for the alpha particles

724 generated within the zircons (Shuster et al. 2006; Reiners et al. 2018).

The evaluation of the thermochronometry ages alone, obtained from the three

726 thermochronometers used in this work and integrated with ages previously published, gives

727 important insights into the thermal behavior of the Uruguayan shield. The higher temperature

728 thermochronometer ZHe ages suggest that most of the shield rocks currently exposed were at

729 temperatures below $200{ }^{\circ} \mathrm{C}$ since the early Paleozoic. The AFT data, of intermediate

730 temperature, indicate that samples passed through temperatures between 100 and $60{ }^{\circ} \mathrm{C}$ from

731 the late Paleozoic to the middle Mesozoic. Finally, the lower temperature thermochronometer

732 AHe suggests that our samples have been accumulating considerable amounts of radiation

733 damage since the late Paleozoic, and that magmatic events in the region, such as the Paraná-

734 Etendeka LIP and the South Atlantic rift, did not raise basement temperatures to the point of

735 resetting AHe ages $\left(>70^{\circ} \mathrm{C}\right)$. Nonetheless, AHe ages dispersion and inverse modeling of the

736 thermal history of our samples suggest that these plate-wide events might have increased

737 UYS temperature during Late Cretaceous, as discussed below. 
740 history for the now exposed basement rocks, but are not consistent regarding the timing of 741 cooling/reheating phases and exhumation/burial events. Based on ZHe and AHe data, Hueck et al. (2017) argued that the shield reached near-surface conditions $\left(<60^{\circ} \mathrm{C}\right)$ in the Silurian and went through subsidence and exhumation cycles during the Paleozoic, related to deposition of Devonian and Permian Paraná Basin sequences over the UYS. According to the authors, these depositional cycles of shallow burial and erosion did not increase basement temperatures over $90{ }^{\circ} \mathrm{C}$. However, models based on AFT data by Kollenz (2015) and Gomes \& Almeida (2019), as well as the multi-thermochronometers models presented here, suggest that most of the shield cooled from the high end of the AFTPRZ $\left(110^{\circ} \mathrm{C}\right)$ only after the Devonian. Therefore, if the UYS rocks were exposed to near surface conditions during the Silurian, a reheating to temperatures above the $110^{\circ} \mathrm{C}$ is necessary to reset the AFT thermochronometer during the Devonian. exposed in the shield NNE and overlie the eastern PAT and western NPT. Provenance studies by Uriz et al. (2016) support the CDT as the main source for the Durazno Group sediments, which corroborates the early onset of cooling and exhumation observed in our models for CDT samples UY2 and UY29. These models, which include ZHe, suggest temperatures

757 above $150{ }^{\circ} \mathrm{C}$ during the Silurian, followed by continuous cooling and exhumation of the samples towards the surface. Thus, the exposure of the CDT to near surface conditions during the Silurian followed by reburial to reset the AFT thermochronometer seems unlikely. The Durazno Group would have been deposited on a rather narrow and N-S oriented depression

761 over the PAT and NPT terranes, which also acted as secondary and proximal detrital sources.

762 In our models, the onset of cooling for these terranes occurs only around the Devonian- 
763 Carboniferous boundary, so they could have been exposed to near surface conditions during

764 the Silurian and buried by the Durazno Group to temperatures over $100{ }^{\circ} \mathrm{C}$ to reset their AFT

765 ages during the Devonian. However, our models for these terranes favor a simpler cooling

766 history, fitting Mesozoic AFT ages with ZHe ages as old as Ordovician in the NPT or young

767 as Permian in the PAT, without the need of exposure to the surface during the Silurian and

768 burial in the Devonian. Moreover, palynomorphs and organic matter in the Durazno Group

769 show little thermal overprint, mostly below $60{ }^{\circ} \mathrm{C}$. All things considered and adopting an

770 Occam's razor principle, exposure of our samples to near surface conditions in the Silurian

771 followed by reset of AFT ages in Devonian seems unlikely, and a continuous protracted

772 cooling of the shield since early to middle Paleozoic until the Mesozoic provide a satisfactory

773 fit to the available data, with onset of cooling occurring earlier in the CDT than in the NPT

774 and PAT.

The main cooling phase that led most of the shield rocks to near surface conditions

776 seems to have started during the Carboniferous-Permian transition (Fig. 10). This denudation-

777 induced cooling is characteristic of models from Group 1 (Fig. 8), in which most samples

778 pass through the AFTPRZ (between 110 and $60{ }^{\circ} \mathrm{C}$ ) from c. 300 Ma until the Jurassic. This

779 behavior is consistent over the PAT, TT and NPT, but less constrained on the CDT, where

780 samples went through cooling since early Paleozoic (UY2 and UY29) or later in the

781 Mesozoic (UY30, UY31 and UY32). Continuous cooling from late Paleozoic to middle

782 Mesozoic is also dominant in AFT models from Kollenz (2015) and Gomes \& Almeida

783 (2019), although some samples from the latter suggest subtle reheating in this period. The

784 onset of this cooling phase is correlated to the Gondwanic cycle, characterized by subduction

785 of the Panthalassa Ocean and accretion of exotic terranes on the SW margin of Gondwana

786 (Fig 1) (Scotese et al. 1999; Milani \& Wit 2008). Intraplate stress transmission linked to

787 these collisions reactivated basement structures below the Paraná Basin and surrounding 
areas (Milani \& Wit 2008), with deformation and exhumation inferred from NE Argentina to southern Brazil until the Triassic (Zambrano \& Urien 1970; Zerfass et al. 2004; Pankhurst et al. 2006; Oliveira et al. 2016; Machado et al. 2019). Therefore, the onset of this major cooling phase in the UYS is likely related to far field propagation stress and deformation caused by the Gondwanic cycle. Furthermore, during the Permian the Gondwana I Supersequence was deposited in the Paraná Basin, with its thickness increasing towards NW Uruguay (de Santa Ana et al. 2006). Paleocurrents of the lower part of this supersequence are preferentially towards the west and NW, and the alluvial, coarse syn-orogenic deposits from the upper part suggest that the Uruguayan shield was a basement high and possibly a limit for deposition (de Santa Ana 2004). However, restricted sedimentation and burial of parts of the UYS might have occurred as well, and could explain local reheating observed in some models from Gomes \& Almeida (2019).

This main cooling phase of the UYS seems to have persisted until the Late Jurassic, when models suggest that our samples reached near surface temperatures $\left(<60{ }^{\circ} \mathrm{C}\right)$. In NW Uruguay, fluvial and aeolian sandstones from the Gondwana III Supersequence (Sprechmann et al. 1981) indicate exposed areas of the Rio de la Plata Craton during the Early Cretaceous (Bossi et al. 1998; de Santa Ana 2004). The continuous and protracted cooling of the UYS, the beginning of which is likely related to intraplate deformation caused by the Gondwanic cycle, might have continued by uplift of the lithosphere preceding the South Atlantic opening (Early Cretaceous). During the Mesozoic the Brazilian margin went through broad epeirogenic uplift, proposed to be related to lithosphere thinning before Gondwana breakup (Tello Saenz et al. 2003; Zalán 2004; Carneiro et al. 2012). Cooling contemporaneous to that found in the UYS was observed in southernmost Brazil (Oliveira et al. 2016; Machado et al. 2019) and can be attributed to increased buoyancy of the lithosphere before rifting, possibly caused by the accumulation of melt in the asthenosphere underneath (Quirk \& Rüpke 2018). 
813 Remarkably, in the Early Cretaceous the voluminous extrusive magmatism of the Paraná-

814 Etendeka Large Igneous Province covered most of the Paraná Basin, with lava flows

815 extending from NE Argentina to central Brazil and Paraguay, and correlative units in

816 southern Africa (Zambrano \& Urien 1970; Turner et al. 1994; Gibson et al. 2006). This

817 magmatism is often associated with the presence of the Tristão da Cunha mantle plume under

818 the region and had its peak at c. $133 \mathrm{Ma}$, closely preceding the opening of the South Atlantic

819 Ocean (Turner et al. 1994; Meisling et al. 2001; Gibson et al. 2006; Rossetti et al. 2014).

820 Rifting in the Atlantic Ocean propagated from SW to NE, and is characterized by

821 intense volcanic activity around the UYS. Besides the Paraná-Etendeka LIP magmatism that

822 covered northern Uruguay, the eastern Uruguayan continental margin possesses broad

823 wedges of magmatic seaward-dipping reflectors, which thicknesses might reach more than a

824 dozen kilometers and width up to one hundred (Soto et al. 2011; Morales et al. 2017; Reuber

825 et al. 2019). Moreover, the spreading rates between South America and Africa increased

826 continuously from $20 \mathrm{~mm} / \mathrm{yr}$ at c. $125 \mathrm{Ma}$ to a peak of $77 \mathrm{~mm} / \mathrm{yr}$ at c. $80 \mathrm{Ma}$ (Granot \&

827 Dyment 2015; Brune et al. 2016), implying in intense magmatic activity at the east of

828 Uruguay. Furthermore, the tectonic stresses related to rifting are thought to have provoked

829 the development of the SaLAM basins, a SW-NE oriented corridor within the shield

830 considered to be an aborted rift precursor to the South Atlantic opening (Rossello et al.

831 2007). The Laguna Merín Basin, NE sector of the SaLAM, is filled with igneous rocks dated

832 between 134 and $127 \mathrm{Ma}$ (Cernuschi et al. 2015). Therefore, during the Cretaceous, the

833 shield was surrounded by active magmatism and likely lying above the Tristão da Cunha

834 plume influence area. It is plausible that this magmatic context had a thermal effect on the

835 UYS, probably increasing the regional geothermal gradient, and possibly causing partial and

836 shallow burial of the shield by lava flows (Kollenz 2015). A reheating episode starting

837 around $140 \mathrm{Ma}$ is suggested by our models from Group 1, with temperatures increasing from 
838 surface conditions to about $60{ }^{\circ} \mathrm{C}$ during Paleogene. It has been argued that such a reheating

839 phase is a modeling artifact caused by problems related to annealing of fission tracks on

840 temperatures below $60{ }^{\circ} \mathrm{C}$ on geological timescales (Jonckheere 2003), and because it is at the

841 limit of resolution of the AFT system, thus poorly constrained. However, the coincidence in

842 time between the beginning of this reheating phase suggested by the models and the

843 magmatic events surrounding the UYS is notable. Moreover, our set of disperse and old AHe

844 ages argue in favor of a slight reheat to temperatures $<70{ }^{\circ} \mathrm{C}$ (Shuster et al. 2006). Therefore,

845 the subtle reheating of the UYS during the Late Cretaceous suggested by the inverse models

846 is supported by evidence of contemporaneous magmatism in the vicinity of the shield. The

847 duration and magnitude of such reheating cannot be constrained by our data, but the models

848 suggest there was regional cooling Neogene.

849 Finally, although our models from Group 2 are in general less robust than Group 1

850 due to the limited number of confined fission tracks, they concur with cooling to

851 temperatures below $60{ }^{\circ} \mathrm{C}$ in the Late Cretaceous, possibly reflecting tectonic adjustments

852 during the final stages of the South Atlantic Oceanic opening, including acid volcanism dated

853 at $77 \pm 1 \mathrm{Ma}$ in the southern NPT (Gaucher et al., 2016). Samples from Group 2 are located

854 in the eastern margin of the shield or near ancient faults and shear zones, structures that

855 played an important role during the rifting along the South American coast (Angelo et al.

856 2018). K-Ar ages on fault gouge also revealed tectonic activity in the Sierra Ballena Shear

857 Zone during Late Cretaceous, related to breakup (Hueck et al. 2017). Therefore, the

858 Gondwana breakup represents a period of intense transformations on the UYS, with

859 movement across old basement structures, intense magmatic events surrounding the shield,

860 and possibly a subtle reheating of the region during the Late Cretaceous. Unfortunately, the

861 precise timing of such reheating and of the final cooling to surface temperature cannot be

862 well defined by our AHe data, but it likely occurred during the Cenozoic. 


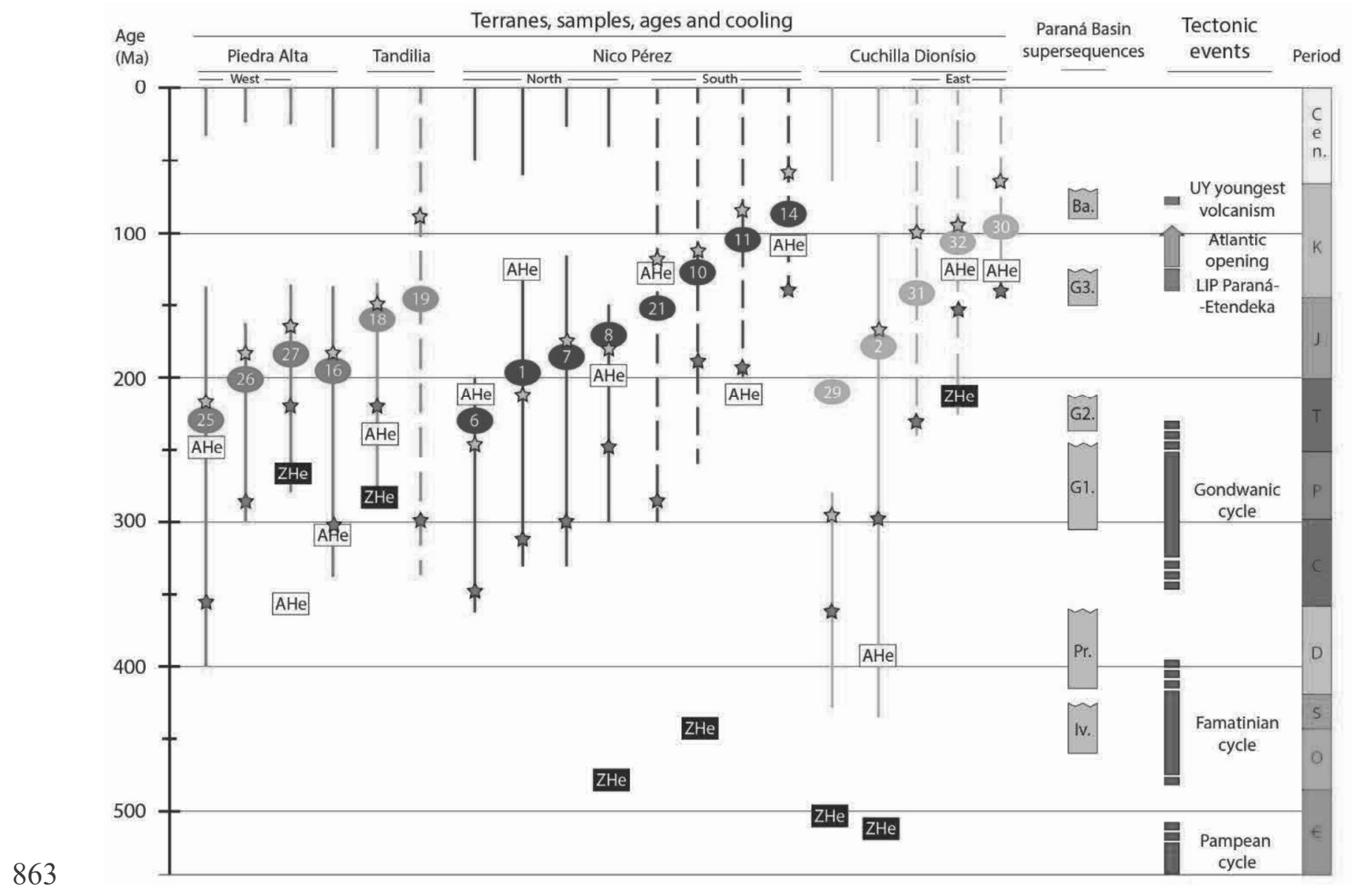

Figure 10. Chronological chart of cooling phases in the Uruguayan shield observed in inverse thermal models. Solid lines represent cooling of samples from Group 1, dashed lines from Group 2. Sample ID placed according to its AFT central age, while the oldest ZHe and youngest AHe corrected ages are reported when available. Red and blue stars indicate the approximated time of passage through temperatures of 110 and $60{ }^{\circ} \mathrm{C}$, respectively. Boxes on the right represent, tectonic and magmatic regional events in the vicinity of the UYS, and the sedimentary record of the Paraná Basin (supergroups Rio Ivaí - Iv., Paraná - Pr., Gondwana I - G1, Gondwana II - G2, Gondwana III - G3, and Bauru - Ba).

\section{Conclusion}

In this work we analyzed the thermal behavior of the Uruguayan shield based on

873 information derived from apatite fission-tracks and apatite and zircon (U-Th)/He

874 thermochronometry. We provided an integrated view of the thermotectonic evolution of the

875 shield, combining 19 new AFT ages, 42 new AHe and 40 new ZHe single crystal ages with

876 data from previous thermochronometry studies. We modeled thermal histories for 19

877 locations across the UYS and compared the results with previously proposed models. Our

878 main conclusions can be summarized as follows:

879 1) Most of the shield reached temperatures below $200{ }^{\circ} \mathrm{C}$ in the early Paleozoic; 
881 Dionísio Terrane, which provided a major sedimentary source for the Devonian deposits of

882

883

884

885

886

887

888

889

890

891

892

893

894

895

896

897

898

899

900

901

902 the Paraná Basin;

3) The main cooling event of the Uruguayan shield began around the CarboniferousPermian boundary, cooling our samples from temperatures above $100{ }^{\circ} \mathrm{C}$ to near surface conditions $\left(<60^{\circ} \mathrm{C}\right)$ by the Jurassic;

4) The onset of this cooling phase is likely related to far field propagation of tectonic stress associated with the Gondwanic cycle on the SW margin of Gondwana;

5) Lithospheric uplift linked to South Atlantic rifting contributed to the continuity of this cooling phase until the Mesozoic;

6) The magmatic events related to Atlantic Ocean opening likely had a positive thermal effect on the Uruguayan shield, subtly increasing temperatures of the basement rocks during the Late Cretaceous; and

7) Final cooling to surface temperatures occurred in the Cenozoic, but the rates and timing cannot be precisely constrained by the available thermochronometry data.

\section{Acknowledgments}

The authors gratefully acknowledge the support from Shell Brasil through the "BG05: UoA-UFRGS-SWB Sedimentary Systems" project at UFRGS and the strategic importance of the support given by ANP through the R\&D levy regulation. The first author thanks the CNPq scholarship (SWE 204254/2017-5) during the exchange period at the University of Aberdeen. A.R. Jelinek also thanks the support from CNPq (Project 303184/2017-5). We thank Peter W. Reiners and his team at the Baja Arizona Radiogenic Helium Dating Laboratory (US) for the (U-Th)/He analyses and support during the data evaluation. 
Angelo, M., Basei, S., Frimmel, H.E., Campos, C., Eduardo, C. \& Araujo, G. De. 2018. Geology of Southwest Gondwana. Springer International Publishing, https://doi.org/10.1007/978-3-319-68920-3.

Basei, M.A.S., Frimmel, H.E., Nutman, A.P., Preciozzi, F. \& Jacob, J. 2005. A connection between the Neoproterozoic Dom Feliciano (Brazil/Uruguay) and Gariep (Namibia/South Africa) orogenic belts - Evidence from a reconnaissance provenance

Basei, M.A.S., Peel, E., Sánchez Bettucci, L., Preciozzi, F., Nutman, A.P., 2011. The basement of the Punta del Este Terrane (Uruguay): an African Mesoproterozoic fragment at the eastern border of the South American Río de la Plata Craton. 
\& Barros, C.E. de. 2003. Significance of Late Paleozoic Fission-track Ages in Volcanic Rocks from the Lavras Do Sul Region, Southernmost Brazil. Gondwana Research, 6, 79-88, https://doi.org/10.1016/S1342-937X(05)70645-6.

Bossi, J., Campal, N., 1992. Magmatismo y tectónica transcurrente durante el Paleozoico Inferior en Uruguay. In: Gutierrez- Marco, J. G., Saavedra, J., Rabano, I. (Eds.): Paleozoico Inferior de Iberoamérica. Mérida, pp 343- 356.

Bossi, J., Ferrando, L., Montaña, J., Campal, N., Morales, H., Gancio, F., Schipilov, A., Piñeyro, D., Sprechmann, P., 1998. Carta geológica del Uruguay. Escala 1:500.000. Geoeditores, Montevideo.

Bossi, J. \& Cingolani, C. 2009. Extension and General Evolution of the Río de la Plata Craton. Developments in Precambrian Geology, https://doi.org/10.1016/S01662635(09)01604-1.

Bossi, J. \& Gaucher, C. 2004. The cuchilla dionisio terrane, Uruguay: An allochthonous block accreted in the Cambrian to SW-Gondwana. Gondwana Research, 7, 661-674, https://doi.org/10.1016/S1342-937X(05)71054-6.

Bossi, J. \& Gaucher, C. 2014a. Estratigrafia del Predevonico del Uruguay. In: Bossi, J. \& Gaucher, C. (eds) Geología Del Uruguay - Tomo 1: Predevónico. Montevideo, 19-42.

Bossi, J. \& Gaucher, C. 2014b. Formacion Valentines. In: Bossi, J. \& Gaucher, C. (eds) Geología Del Uruguay - Tomo 1: Predevónico. 171-189.

Bossi, J. \& Piñeyro, D. 2014. Terreno Piedra Alta. In: Bossi, J. \& Gaucher, C. (eds) Geología Del Uruguay - Tomo 1: Predevónico. Montevideo, 43-86.

Bossi, J., Ferrando, L., et al. 1998. Carta geológica del Uruguay. Escala 1:500.000.

Bossi, J., Gaucher, C., Chiglino, L., Navarro, R. \& Piñeyro, D. 2014. Escama Tectonica Carape. In: Bossi, J. \& Gaucher, C. (eds) Geología Del Uruguay - Tomo 1: Predevónico. $265-282$. 
Brown, R.W., Beucher, R., Roper, S., Persano, C., Stuart, F. \& Fitzgerald, P. 2013. Natural age dispersion arising from the analysis of broken crystals. Part I: Theoretical basis and implications for the apatite (U-Th)/He thermochronometer. Geochimica et Cosmochimica Acta, 122, 478-497, https://doi.org/10.1016/j.gca.2013.05.041.

Brune, S., Williams, S.E., Butterworth, N.P. \& Müller, R.D. 2016. Abrupt plate accelerations shape rifted continental margins. Nature, 536, 201-204, https://doi.org/10.1038/nature18319.

Carlson, W.D., Donelick, R.A. \& Ketcham, R.A. 1999. Variability of apatite fission-track annealing kinetics: I. Experimental results. American Mineralogist, 84, 1213-1223, https://doi.org/10.2138/am-1999-0901.

Carneiro, C.D.R., Almeida, F.F.M. de, Hasui, Y., Zalán, P. V. \& Teixeira, J.B.G. 2012. Estagios Evolutivos do Brasil no Fanerozoico. In: Hasui, Y., Carneiro, C. D. R., Almeida, F. F. M. de \& Bartorelli, A. (eds) Geologia Do Brasil. São Paulo, Editora Beca, 131-137.

Cernuschi, F., Dilles, J.H., Kent, A.J.R., Schroer, G., Raab, A.K., Conti, B. \& Muzio, R. 2015. Geology, geochemistry and geochronology of the Cretaceous Lascano East intrusive complex and magmatic evolution of the Laguna Merín basin, Uruguay. Gondwana Research, 28, 837-857, https://doi.org/10.1016/j.gr.2014.07.007.

Chiglino, L., Gaucher, C., Sial, A.N., Bossi, J., Ferreira, V.P., Pimentel, M.M., 2010. Chemostratigraphy of Mesoproterozoic and Neoproterozoic carbonates of the Nico Pérez Terrane, Río de la Plata Craton, Uruguay. Precambrian Research 182, 313336.

Cogné, N., Gallagher, K. \& Cobbold, P.R. 2011. Post-rift reactivation of the onshore margin of southeast Brazil: Evidence from apatite (U-Th)/He and fission-track data. Earth and Planetary Science Letters, 309, 118-130, https://doi.org/10.1016/j.eps1.2011.06.025. 
978 Cogné, N., Gallagher, K., Cobbold, P.R., Riccomini, C. \& Gautheron, C. 2012. Post-breakup

979

980

981

982

983

984

985

986

987

988

989

990

991

992

993

994

995

996

997

998

999

1000

1001

1002 tectonics in southeast Brazil from thermochronological data and combined inverseforward thermal history modeling. Journal of Geophysical Research B: Solid Earth, 117, 1-16, https://doi.org/10.1029/2012JB009340.

De Santa Ana, H., Veroslavsky, G., Fúlfaro, V., Rossello, E. 2006. Cuenca Norte: evolución tectónica y sedimentaria del Carbonífero-Pérmico. En: Veroslavsky, G., Ubilla, M., Martínez, S. (Eds.): Cuencas sedimentarias de Uruguay. Paleozoico. Facultad de Ciencias, Montevideo, pp. 209-244.

de Santa Ana, H. 2004. Análise Tectono-Estratigráfica Das Seqüências Chacoparanense Uruguaia ("Cuenca Norte ”). Universidade Estadual Paulista.

Dodson, M.H. 1973. Closure temperature in cooling geochronological and petrological systems. Contributions to Mineralogy and Petrology, 40, 259-274, https://doi.org/10.1007/BF00373790.

Donelick, R.A. 1993. Method of Fission Track Analysis Utilizing Bulk Chemical Etching of Apatite. 35.

Donelick, R.A., Ketcham, R.A. \& Carlson, W.D. 1999a. Variability of apatite fission-track annealing kinetics: II. Crystallographic orientation effects. American Mineralogist, 84, 1224-1234, https://doi.org/10.2138/am-1999-0902.

Donelick, R.A., Ketcham, R.A. \& Carlson, W.D. 1999b. Variability of apatite fission-track annealing kinetics: II. Crystallographic orientation effects. American Mineralogist, 84, 1224-1234, https://doi.org/10.2138/am-1999-0901.

Donelick, R.A., O’Sullivan, P.B. \& Ketcham, R.A. 2005. Apatite Fission-Track Analysis. In: Reiners, P. W. \& Ehlers, T. A. (eds) Low-Temperature Thermochronology: Techniques, Interpretations, and Applications. Mineralogical Society of America, 49-94.

Faraone, M., 2018. Geología, petrografía y aspectos estructurales del extremo sur-occidental 
de la Zona de Cizalla Sarandí del Yí (área SW de Solís de Mataojo). Degree Thesis, Facultad de Ciencias, Montevideo.

Farley, K.A. 2000. Helium diffusion from apatite: General behavior as illustrated by Durango fluorapatite. Journal of Geophysical Research: Solid Earth, 105, 2903-2914,

Farley, K.A. 2002. (U-Th)/He Dating: Techniques, Calibrations, and Applications. Reviews in Mineralogy and Geochemistry, 47, 819-844, https://doi.org/10.2138/rmg.2002.47.18.

Farley, K.A., Wolf, R.A. \& Silver, L.T. 1996. The effects of long alpha-stopping distances on (U-Th)/He ages. Geochimica et Cosmochimica Acta, 60, 4223-4229, https://doi.org/10.1016/S0016-7037(96)00193-7.

Fernandes, L.A.D.A. \& Koester, E. 1999. The Neoproterozoic Dorsal de Cangucu strike-slip shear zone: Its nature and role in the tectonic evolution of southern Brazil. Journal of African Earth Sciences, 29, 3-24, https://doi.org/10.1016/S0899-5362(99)00076-7.

Fernandes, L.A.D.A., TOMMASI, A., VAUCHEZ, A., PORCHER, C.C., MENEGAT, R. \& KOESTER, E. 1993. Zona De Cisalhamento Transcorrente Dorsal De Canguçu: Caracterização E Importância Na Compartimentação Tectônica Do Cinturão Dom Feliciano. Revista Brasileira de Geociências, 23, 224-233, Applications. California, University of California Press.

1027 Flowers, R.M. \& Kelley, S.A. 2011. Interpreting data dispersion and 'inverted' dates in 

apatite (U-Th)/He and fission-track datasets: An example from the US midcontinent. Geochimica et Cosmochimica Acta, 75, 5169-5186, https://doi.org/10.1016/j.gca.2011.06.016.

Flowers, R.M., Shuster, D.L., Wernicke, B.P. \& Farley, K.A. 2007. Radiation damage control on apatite (U-Th)/He dates from the Grand Canyon region, Colorado Plateau. Geology, 35, 447, https://doi.org/10.1130/G23471A.1.

Flowers, R.M., Ketcham, R.A., Shuster, D.L. \& Farley, K.A. 2009. Apatite (U-Th)/He thermochronometry using a radiation damage accumulation and annealing model. Geochimica et Cosmochimica Acta, 73, 2347-2365, https://doi.org/10.1016/j.gca.2009.01.015.

Galbraith, R.F. 1981. On statistical models for fission track counts. Journal of the International Association for Mathematical Geology, 13, 471-478, https://doi.org/10.1007/BF01034498.

Galbraith, R.F. \& Green, P.F. 1990. Estimating the component ages in a finite mixture. International Journal of Radiation Applications and Instrumentation. Part D. Nuclear Tracks and Radiation Measurements, 17, 197-206, https://doi.org/10.1016/13590189(90)90035-V.

Galbraith, R.F., Laslett, G.M., Green, P.F. \& Duddy, I.R. 1990. Apatite fission track analysis: geological thermal history analysis based on a three-dimensional random process of linear radiation damage. Philosophical Transactions of the Royal Society of London. Series A: Physical and Engineering Sciences, 332, 419-438, https://doi.org/10.1098/rsta.1990.0124.

Gallagher, K. 2012. Transdimensional inverse thermal history modeling for quantitative thermochronology. Journal of Geophysical Research: Solid Earth, 117, 1-16, https://doi.org/10.1029/2011JB008825. 
1053 Gallagher, K. \& Brown, R. 1997. The onshore record of passive margin evolution. Journal of the Geological Society, 154, 451-457, https://doi.org/10.1144/gsjgs.154.3.0451.

1055 Gallagher, K. \& Brown, R.W. 1999. The Mesozoic denudation history of the Atlantic margins of southern Africa and southeast Brazil and the relationship to offshore sedimentation. Geological Society, London, Special Publications, 153, 41-53, https://doi.org/10.1144/GSL.SP.1999.153.01.03.

Gallagher, K., Hawkesworth, C.J. \& Mantovani, M.S.M. 1994. The denudation history of the onshore continental margin of SE Brazil inferred from apatite fission track data. Journal of Geophysical Research: Solid Earth, 99, 18117-18145, https://doi.org/10.1029/94JB00661.

Gallagher, K., Hawkesworth, C.J. \& Mantovani, M.S.M. 1995. Denudation, fission track analysis and the long-term evolution of passive margin topography: application to the southeast Brazilian margin. Journal of South American Earth Sciences, 8, 65-77, https://doi.org/10.1016/0895-9811(94)00042-Z.

Gallagher, K., Charvin, K., Nielsen, S., Sambridge, M. \& Stephenson, J. 2009. Markov chain Monte Carlo ( MCMC ) sampling methods to determine optimal models, model resolution and model choice for Earth Science problems. Marine and Petroleum Geology, 26, 525-535, https://doi.org/10.1016/j.marpetgeo.2009.01.003.

Gaucher, C., 2000. Sedimentology, palaeontology and stratigraphy of the Arroyo del Soldado Group (Vendian to Cambrian, Uruguay). Beringeria 26, 1-120.

Gaucher, C., Babinski, M., Blanco, G. 2016. Riolitas del Cretácico Superior (Campaniense); el magmatismo más joven de Uruguay. In: VIII Congreso Uruguayo de Geología, Actas, pp. 160-161, Montevideo.

Gaucher, C., Bossi, J., Blanco, G., 2009a. Palaeogeography. Neoproterozoic-Cambrian evolution of the Río de la Plata Palaeocontinent. In: Gaucher, C., Sial, A.N., Halverson, 

G.P., Frimmel, H.E. (Eds): Neoproterozoic-Cambrian Tectonics, Global Change and Evolution: a focus on southwestern Gondwana. Developments in Precambrian Geology, 16, Elsevier, pp. 131-141 .

Gaucher, C., Bossi, J., Samaniego, L., Frei, R., 2014a. Complejo Tapes. In: Bossi, J., Gaucher, C. (Eds.) Geología del Uruguay. Tomo 1: Predevónico. Polo, Montevideo, pp. 253-264.

Gaucher, C., Finney, S.C., Poiré, D.G., Valencia, V.A., Grove, M., Blanco, G., Pamoukaghlián, K., Gómez Peral, L., 2008. Detrital zircon ages of Neoproterozoic sedimentary successions in Uruguay and Argentina: insights into the geological evolution of the Río de la Plata Craton. Precambrian Research 167, 150-170.

Gaucher, C., Frei, R., Sial, A.N., Castiglioni, E., Ferreira, V.P., 2014b. Grupo Cebollatí. In: Bossi, J., Gaucher, C. (Eds.) Geología del Uruguay. Tomo 1: Predevónico. Polo, Montevideo, pp. 155-169.

Gaucher, C.; Frimmel, H.E., Germs, G.J.B. 2009b. Tectonic events and palaeogeographic evolution of southwestern Gondwana in the Neoproterozoic and Cambrian. In: Gaucher, C., Sial, A.N., Halverson, G.P., Frimmel, H.E. (Eds): Neoproterozoic-Cambrian Tectonics, Global Change and Evolution: a focus on southwestern Gondwana. Developments in Precambrian Geology, 16, Elsevier, pp. 295-316.

Gaucher, C., Nóbrega Sial, A., Blanco, G. \& Sprechmann, P. 2004. Chemostratigraphy of the lower Arroyo del soldado group (Vendian, Uruguay ) and palaeoclimatic implications. Gondwana Research, 7, 715-730, https://doi.org/10.1016/S1342-937X(05)71058-3.

Gaucher, C., Chemale, F., Bossi, J. \& Castiglioni, E.A. 2010. Grupo Cebollattí, Tererno Nico Perez: definición y edad. VI Congreso Uruguayo de Geología, Minas.

Gaucher, C., Frei, R., et al. 2011. Mesoproterozoic evolution of the Río de la Plata Craton in Uruguay: At the heart of Rodinia? International Journal of Earth Sciences, 100, 273- 

288, https://doi.org/10.1007/s00531-010-0562-x.

1104 Gibson, S.A., Thompson, R.N. \& Day, J.A. 2006. Timescales and mechanisms of plume1105 lithosphere interactions: 40Ar/39Ar geochronology and geochemistry of alkaline 1106 igneous rocks from the Paraná-Etendeka large igneous province. Earth and Planetary 1107 Science Letters, 251, 1-17, https://doi.org/10.1016/j.eps1.2006.08.004.

1108 Gleadow, A.J.W. 1981. Fission-track dating methods: What are the real alternatives? Nuclear Tracks, 5, 3-14, https://doi.org/10.1016/0191-278X(81)90021-4.

1110 Gleadow, A.J.W., Duddy, I.R., Green, P.F. \& Lovering, J.F. 1986a. Confined fission track 1111 lengths in apatite: a diagnostic tool for thermal history analysis. Contributions to 1112 Mineralogy and Petrology, 94, 405-415, https://doi.org/10.1007/BF00376334.

1113 Gleadow, A.J.W., Duddy, I.R., Green, P.F. \& Hegarty, K.A. 1986b. Fission track lengths in 1114 the apatite annealing zone and the interpretation of mixed ages. Earth and Planetary 1115 Science Letters, 78, 245-254, https://doi.org/10.1016/0012-821X(86)90065-8.

1116 Gomes, C.H. \& Almeida, D. 2019. New insights into the Gondwana breakup at the Southern 1117 South America by apatite fission-track analyses. Advances in Geosciences, 47, 1-15, 1118 https://doi.org/10.5194/adgeo-47-1-2019.

1119 Granot, R. \& Dyment, J. 2015. The Cretaceous opening of the South Atlantic Ocean. Earth $1120 \quad$ and Planetary Science Letters, 414, 156-163, https://doi.org/10.1016/j.eps1.2015.01.015.

1121 Green, P.F. 1986. On the thermo-tectonic evolution of Northern England: Evidence from 1122 fission track analysis. Geological Magazine, 123, 493-506, $1123 \quad$ https://doi.org/10.1017/S0016756800035081.

1124 Green, P.F. \& Duddy, I.R. 2006. Interpretation of apatite (U-Th)/He ages and fission track ages from cratons. Earth and Planetary Science Letters, 244, 541-547,

1126 https://doi.org/10.1016/j.eps1.2006.02.024.

1127 Guenthner, W.R., Reiners, P.W., Ketcham, R.A., Nasdala, L. \& Giester, G. 2013. Helium 
diffusion in natural zircon: radiation damage, anisotropy, and the interpretation of zircon (U-TH)/He thermochronology. American Journal of Science, 313, 145-198, https://doi.org/10.2475/03.2013.01.

1131

1132

1133

1134

1135

1136

1137

1138

1139

1140

1141

1142

1143

1144

1145

1146

1147

1148

1149

1150

1151

1152

Hackspacher, P.C., Ribeiro, L.F.B., Ribeiro, M.C.S., Fetter, A.H., Hadler Neto, J.C., Tello, C.E.S. \& Dantas, E.L. 2004. Consolidation and break-up of the South American Platform in southeastern Brazil: Tectonothermal and denudation histories. Gondwana Research, 7, 91-101, https://doi.org/10.1016/S1342-937X(05)70308-7.

Hartmann, L.A., Campal, N., Santos, J.O.S., McNaughton, N.J., Bossi, J., Schipilov, A. \& Lafon, J.M. 2001. Archean crust in the Rio de la Plata Craton, Uruguay - SHRIMP U-Pb zircon reconnaissance geochronology. Journal of South American Earth Sciences, 14, 557-570, https://doi.org/10.1016/S0895-9811(01)00055-4.

Hartmann, L.A., Santos, J.O.S., Cingolani, C.A., McNaughton, N.J. 2002. Two Paleoproterozoic Orogenies in the Evolution of the Tandilia Belt, Buenos Aires, as evidenced by zircon U-Pb SHRIMP geochronology. International Geology Review, 44: 528-543.

Hueck, M., Oriolo, S., et al. 2017. Phanerozoic low-temperature evolution of the Uruguayan Shield along the South American passive margin. Journal of the Geological Society of London, https://doi.org/10.1144/jgs2016-101.

Hueck, M., Dunkl, I., Heller, B., Angelo, M., Basei, S. \& Siegesmund, S. 2018a. ( U-Th )/ He Thermochronology and Zircon Radiation Damage in the South American Passive Margin : Thermal Overprint of the Paraná LIP ? 1-18, https://doi.org/10.1029/2018TC005041.

Hueck, M., Oyhantçabal, P., Philipp, R.P., Angelo, M., Basei, S. \& Siegesmund, S. 2018b. The Dom Feliciano Belt in Southern Brazil and Uruguay. Siegesmund, S., Basei, M. A. S., Oyhantçabal, P. \& Oriolo, S. (eds). Cham, Springer International Publishing, 
Regional Geology Reviews, https://doi.org/10.1007/978-3-319-68920-3.

1154 Hurford, A.J. 1990. Standardization of Fission-Track Dating Calibration - Recommendation

1155 by the Fission-Track Working Group of the Iugs Subcommission on Geochronology.

1156 Chemical Geology, 80, 171-178 ST-Standardization of Fission-Track Dat.

1157 Hurford, A.J. \& Green, P.F. 1983. The zeta age calibration of fission-track dating. Chemical

1158 Geology, 41, 285-317, https://doi.org/10.1016/S0009-2541(83)80026-6.

1159 Jelinek, A.R., Cezar, A., Neto, B. \& Poupeau, G. 2003. Análise Por Traços De Fissão Em

1160 Apatitas Do Distrito Fluorítico De Santa Catarina : Relações Entre Hidrotermalismo E

1161 Evolução Da Margem Continental. Recherche, 33, 289-298.

1162 Jonckheere, R. 2003. On methodical problems in estimating geological temperature and time

1163 from measurements of fission tracks in apatite. Radiation Measurements, 36, 43-55,

1164 https://doi.org/10.1016/S1350-4487(03)00096-9.

1165 Karl, M., Glasmacher, U.A., Kollenz, S., Franco-Magalhaes, A.O.B., Stockli, D.F. \&

1166 Hackspacher, P.C. 2013. Evolution of the South Atlantic passive continental margin in

1167 southern Brazil derived from zircon and apatite (U-Th-Sm)/He and fission-track data.

1168 Tectonophysics, 604, 224-244, https://doi.org/10.1016/j.tecto.2013.06.017.

1169 Ketcham, R.A. 2005. Forward and Inverse Modeling of Low-Temperature

1170 Thermochronometry Data. Reviews in Mineralogy and Geochemistry, 58, 275-314,

$1171 \quad$ https://doi.org/10.2138/rmg.2005.58.11.

1172 Ketcham, R.A., Donelick, R.A. \& Donelick, M.B. 2000. AFTSolve: A program for multi-

1173 kinetic modeling of apatite fission-track data. American Mineralogist, 88, 929.

1174 Ketcham, R.A., Carter, A., Donelick, R.A., Barbarand, J. \& Hurford, A.J. 2007. Improved

1175 modeling of fission-track annealing in apatite. American Mineralogist, 92, 799-810,

1176 https://doi.org/10.2138/am.2007.2281.

1177 Kollenz, S. 2015. Long-Term Landscape Evolution, Cooling and Exhumation History of the 
1179 Kollenz, S., Glasmacher, U.A., Rossello, E.A., Stockli, D.F., Schad, S. \& Pereyra, R.E. 2017.

1180 Thermochronological constraints on the Cambrian to recent geological evolution of the

$1181 \quad$ Argentina passive continental margin. Tectonophysics, 716, 182-203,

$1182 \quad$ https://doi.org/10.1016/j.tecto.2016.11.019.

1183 Krob, F.C., Glasmacher, U.A., Karl, M., Perner, M., Hackspacher, P.C. \& Stockli, D.F. 2019.

1184 Multi-chronometer thermochronological modelling of the Late Neoproterozoic to recent

1185 t-T-evolution of the SE coastal region of Brazil. Journal of South American Earth

$1186 \quad$ Sciences, 92, 77-94, https://doi.org/10.1016/j.jsames.2019.02.012.

1187 Lal, D., Rajan, R.S. \& Tamhane, A.S. 1969. Chemical Composition of Nuclei of Z > 22 in

1188 Cosmic Rays using Meteoritic Minerals as Detectors. Nature, 211, 33-37,

$1189 \quad$ https://doi.org/10.1038/221033a0.

1190 Machado, J.P.S.L., Jelinek, A.R., Bicca, M.M., Stephenson, R. \& Genezini, F.A. 2019. West

1191 Gondwana orogenies and Pangaea breakup: thermotectonic effects on the southernmost

1192 Mantiqueira Province, Brazil. Journal of the Geological Society, jgs2019-018,

$1193 \quad$ https://doi.org/10.1144/jgs2019-018.

1194 Mallmann, G., Chemale, F., Ávila, J.N., Kawashita, K. \& Armstrong, R.A. 2007. Isotope

1195 geochemistry and geochronology of the Nico Pérez Terrane, Rio de la Plata Craton,

1196 Uruguay. Gondwana Research, 12, 489-508, https://doi.org/10.1016/j.gr.2007.01.002.

1197 Masquelin, H. 2006. El Escudo Uruguayo. In: Cuencas Sedimentarias Del Uruguay. DIRAC

$1198 \quad$ Facultad de Ciencias, 37-106.

1199 Meisling, K.E., Cobbold, P.R. \& Mount, V.S. 2001. Segmentation of an obliquely rifted

1200 margin, Campos and Santos basins, southeastern Brazil. AAPG Bulletin, 85, 1903-1924,

1201 https://doi.org/10.1306/8626D0B3-173B-11D7-8645000102C1865D.

1202 Milani, E.J. 1997. Evolução Tectono-Estratigráfica Da Bacia Do Paraná e Seu 

Universidade Federal do Rio Grande do Sul.

Milani, E.J. \& Wit, M.J. De. 2008. Correlations between the classic Paraná and Cape - Karoo

Milani, E.J., Melo, J.H.G. de, Souza, P.A. De, Fernandes, L.A. \& França, A.B. 2007. Bacia do Paraná. Boletim de Geociências da Petrobras, 8, 265-287.

Morales, E., Chang, H.K., et al. 2017. Tectonic and stratigraphic evolution of the Punta del Este and Pelotas basins (offshore Uruguay). Petroleum Geoscience, 23, 415-426, https://doi.org/10.1144/petgeo2016-059.

Murray, K.E., Orme, D.A. \& Reiners, P.W. 2014. Effects of U-Th-rich grain boundary phases on apatite helium ages. Chemical Geology, 390, 135-151,

Nasdala, L., Reiners, P.W., Garver, J.I., Kennedy, A.K., Stern, R.A., Balan, E. \& Wirth, R.

Oliveira, C.H.E. de, Jelinek, A.R., Chemale, F. \& Bernet, M. 2016. Evidence of post-

Oriolo, S., Oyhantçabal, P., Basei, M.A.S., Wemmer, K. \& Siegesmund, S. 2016a. The Nico Pérez Terrane (Uruguay): From Archean crustal growth and connections with the Congo Craton to late Neoproterozoic accretion to the Río de la Plata Craton. Precambrian Research, 280, 147-160, https://doi.org/10.1016/j.precamres.2016.04.014. 
1228 Oriolo, S., Oyhantçabal, P., et al. 2016b. Timing of deformation in the Sarandí del Yí Shear 1229 Zone, Uruguay: Implications for the amalgamation of western Gondwana during the 1230 Neoproterozoic Brasiliano-Pan-African Orogeny. Tectonics, 35, 754-771, $1231 \quad$ https://doi.org/10.1002/2015TC004052.

1232 Oriolo, S., Hueck, M., Oyhantçabal, P., Goscombe, B., Wemmer, K. \& Siegesmund, S. 2018. 1233 Shear Zones in Brasiliano-Pan-African Belts and Their Role in the Amalgamation and 1234 Break-Up of Southwest Gondwana. In: Geology of Southwest Gondwana. Springer International Publishing, 593-613., https://doi.org/10.1007/978-3-319-68920-3.

Oyhantçabal, P., Siegesmund, S. \& Wemmer, K. 2011. The Río de la Plata Craton: A review

Oyhantçabal, P.B., Wagner-Eimer, M., Wemmer, K., Schulz, B., Frei, R., Siegesmund, S., 2012. Paleo- and Neoproterozoic magmatic and tectonometamorphic evolution of the Isla Cristalina de Rivera (Nico Pérez Terrane, Uruguay). International Journal of Earth Sciences 101, 1745-1762.

Oyhantçabal, P., Cingolani, C.A. \& Wemmer, K. 2018. The Río de La Plata Craton of Argentina and Uruguay. Springer International Publishing, https://doi.org/10.1007/9783-319-68920-3.

Pamoukaghlián, K., Gaucher, C., Frei, R., Poiré, D. G., Chemale, F., Frei, D., Will, T. M., 2017. U-Pb age constraints for the La Tuna Granite and Montevideo Formation (Paleoproterozoic, Uruguay): Unravelling the structure of the Río de la Plata Craton. Journal of South American Earth Sciences 79, 443-458.

Panario, D., Gutierrez, O., Bettucci, L.S., Peel, E., Oyhantçabal, P. \& Raba. 2014. Ancient Landscapes of Uruguay. In: Gondwana Landscapes in Southern South America: Argentina, Uruguay and Southern Brazil. 1-545., https://doi.org/10.1007/978-94-007- 
1254 Pankhurst, R.J., Rapela, C.W., Fanning, C.M. \& Márquez, M. 2006. Gondwanide continental collision and the origin of Patagonia. Earth-Science Reviews, 76, 235-257, https://doi.org/10.1016/j.earscirev.2006.02.001

Peel, E., Sánchez Bettucci, L., Basei, M.A.S., 2018. Geology and geochronology of Paso del Dragón Complex (northeastern Uruguay): implications on the evolution of the Dom Feliciano Belt (Western Gondwana). J. South Amer. Earth Sci. 85, 250-262.

1260 Philipp, R.P., Pimentel, M.M. \& Chemale, F. 2016. Tectonic evolution of the Dom Feliciano Belt in Southern Brazil: Geological relationships and U-Pb geochronology. Brazilian Journal of Geology, 46, 83-104, https://doi.org/10.1590/2317-4889201620150016.

Philipp, R.P., Pimentel, M.M. \& Basei, M.A.S. 2018. The Tectonic Evolution of the São Gabriel Terrane, Dom Feliciano Belt, Southern Brazil: The Closure of the Charrua Ocean. In: Geology of Southwest Gondwana. Springer International Publishing, 243265., https://doi.org/10.1007/978-3-319-68920-3.

1267 Price, P.B. \& Walker, R.M. 1963. Fossil tracks of charged particles in mica and the age of

Rapela, C.W., Fanning, C.M., Casquet, C., Pankhurst, R.J., Spalletti, L., Poiré, D. \& Baldo, E.G. 2011. The Rio de la Plata craton and the adjoining Pan-African/brasiliano terranes: Their origins and incorporation into south-west Gondwana. Gondwana Research, 20, 673-690, https://doi.org/10.1016/j.gr.2011.05.001.

Reiners, P.W. 2005. Zircon (U-Th)/He Thermochronometry. In: Reviews in Mineralogy and 

Geochemistry. 151-179., https://doi.org/10.2138/rmg.2005.58.6.

Reiners, P.W. \& Farley, K.A. 2001. Influence of crystal size on apatite (U-Th)/He thermochronology: An example from the Bighorn Mountains, Wyoming. Earth and Planetary Science Letters, 188, 413-420, https://doi.org/10.1016/S0012821X(01)00341-7.

Reiners, P.W., Farley, K.A. \& Hickes, H.J. 2002. He diffusion and (U-Th)/He thermochronometry of zircon: Initial results from Fish Canyon Tuff and Gold Butte. Tectonophysics, 349, 297-308, https://doi.org/10.1016/S0040-1951(02)00058-6.

Reiners, P.W., Spell, T.L., Nicolescu, S. \& Zanetti, K.A. 2004. Zircon (U-Th)/He thermochronometry: He diffusion and comparisons with 40Ar/39Ar dating. Geochimica et Cosmochimica Acta, 68, 1857-1887, https://doi.org/10.1016/j.gca.2003.10.021.

Reiners, P.W., Carlson, R.W., Renne, P.R., Cooper, K.M., Granger, D.E., McLean, N.M. \& Schoene, B. 2018. The (U-Th)He system. In: Geochronology and Thermochronology. John Wiley \& Sons Ltd., 291-363.

Ribot, A., Bossi, J., Cingolani, C.A., Piñeyro, D. 2005. Caracterización petrográfica de la faja milonítica Colonia-Arroyo Pavón en el Sur del Terreno Piedra Alta, Uruguay: Zona de cizalla principal en basamento precámbrico? Actas $16^{\circ}$ Congreso Geológico Argentino, 789, La Plata.

Reuber, K., Mann, P. \& Pindell, J. 2019. Hotspot Origin for Asymmetrical Conjugate Volcanic Margins of the Austral South Atlantic Ocean As Imaged on DeeplyPenetrating Seismic Reflection Images. Interpretation, 1-88, https://doi.org/10.1190/int2018-0256.1.

Rossello, E.A., De Santa Ana, H. \& Veroslavsky, G. 2000. El lineamiento Santa LuciaAigua-Merin (Uruguay): un corredor tectonico extensivo y transcurrente dextral precursos de la apertura atlantica. Revista Brasileira de Geociências, 30, 749-756. 
1303 Rossello, E.A., Veroslavsky, G., Masquelin, H. \& De Santa Ana, H. 2007. El corredor juro1304 cretácico Santa Lucía-Aiguá-Merín (Uruguay): Evidencias cinemática transcurrente 1305 dextral y controles preexistentes. Revista de la Asociacion Geologica Argentina, 62, 92$1306 \quad 104$.

1307 Rossetti, L.M., Lima, E.F., Waichel, B.L., Scherer, C.M. \& Barreto, C.J. 2014.

1308 Stratigraphical framework of basaltic lavas in Torres Syncline main valley, southern 1309 Parana-Etendeka Volcanic Province. Journal of South American Earth Sciences, 56, 1310 409-421, https://doi.org/10.1016/j.jsames.2014.09.025.

1311 Santos, J.OS., Hartmann, L.A., Bossi, J., Campal, N., Schipilov, A., Piñeyro, D., 1312 McNaughton, N.J., 2003. Duration of the Transamazonian and its correlation within 1313 South America based on U-Pb SHRIMP geochronology of the la Plata Craton, Uruguay. 1314 International Geology Review 45, 27-48.

1315 Santos, J. O., Chernicoff, C. J., Zappettini, E. O., McNaughton, N. J., Greau, Y. 2017. U-Pb 1316 geochronology of Martín García, Sola, and Dos Hermanas Islands (Argentina and 1317 Uruguay): Unveiling Rhyacian, Statherian, Ectasian, and Stenian of a forgotten area of 1318 the Río de la Plata Craton. Journal of South American Earth Sciences, 80, 207-228.

1319 Schmitt, R. da S., Fragoso, R.D.A. \& Collins, A.S. 2018. Suturing Gondwana in the 1320 Cambrian: The Orogenic Events of the Final Amalgamation. In: Geology of Southwest 1321 Gondwana. Springer International Publishing, 411-432., https://doi.org/10.1007/978-31322 319-68920-3_15.

1323 Scotese, C.R., Boucot, A.J. \& McKerrow, W.S. 1999. Gondwanan palaeogeography and 1324 palaeoclimatology. Journal of African Earth Sciences, 28, 99-114. on helium diffusion kinetics in apatite. Earth and Planetary Science Letters, 249, 148 161, https://doi.org/10.1016/j.eps1.2006.07.028. 
1328

1329

1330

1331

1332

1333

1334

1335

1336

1337

1338

1339

1340

1341

1342

1343

1344

1345

1346

1347

1348

1349

1350

1351

1352

Soto, M., Morales, E., Veroslavsky, G., de Santa Ana, H., Ucha, N. \& Rodríguez, P. 2011. The continental margin of uruguay: Crustal architecture and segmentation. Marine and Petroleum Geology, 28, 1676-1689, https://doi.org/10.1016/j.marpetgeo.2011.07.001.

Sprechmann, P., Bossi, J., Da Silva, J. 1981. Cuencas del Jurásico y Cretácico del Uruguay. In: Volkheimer, W., Musacchio (Eds.) Cuencas sedimentarias del Jurásico y Cretácico de América del Sur, 1, pp. 239-270, Buenos Aires.

Sprechmann, P., Montaña, J., Gaucher, C. 1993. Devónico. In: Bossi, J. (Ed.): Geología y Recursos Minerales del Departamento de Durazno. Intendencia Municipal de Durazno y Cátedra de Geología de la Facultad de Agonomía, Montevideo, pp. 25-55.

Stockli, D.F. 2005. Application of low-temperature thermochronometry to extensional tectonic settings. In: Reiners, P. W. \& Ehlers, T. A. (eds) Low-Temperature Thermochronology: Techniques, Interpretations, and Applicationscations. Mineralogical Society of America, 411-448.

Stockli, D.F., Farley, K.A. \& Dumitru, T.A. 2000. Calibration of the apatite ( U-Th )/ He thermochronometer on an exhumed fault block, White Mountains, California. Geology, 28, 983-986, https://doi.org/10.1130/0091-7613(2000)28<983.

Tagami, T. \& O’Sullivan, P.B. 2005. Fundamentals of fission-track thermochronology. In: Reiners, P. W. \& Ehlers, T. A. (eds) Low-Temperature Thermochronology: Techniques, Interpretations, and Applications. Mineralogical Society of America, 19-48.

Teixeira W., Renne, P., Bossi. J., Campal, N., D’Agrella, F., 1999. ${ }^{40} \mathrm{Ar} /{ }^{39} \mathrm{Ar}$ and Rb/Sr geochronology of the Uruguayan dike swarm, Río de la Plata Craton and implications for Proterozoic intraplate activity in western Gondwana. Precambrian Research, 93, 153180.

Tello Saenz, C.A., Hackspacher, P.C., et al. 2003. Recognition of Cretaceous, Paleocene, and Neogene tectonic reactivation through apatite fission-track analysis in Precambrian areas 

of southeast Brazil: association with the opening of the south Atlantic Ocean. Journal of South American Earth Sciences, 15, 765-774, https://doi.org/10.1016/S08959811(02)00131-1.

Turner, S., Regelous, M., et al. 1994. Magmatism and Continental Break-Up in the South Atlantic. Earth. Planet. Sci. Lett., 121, 333-348, https://doi.org/10.1016/0012821X(94)90076-0.

Uriz, N.J., Cingolani, C.A., Basei, M.A.S., Blanco, G., Abre, P., Portillo, N.S. \& Siccardi, A. 2016. Provenance and paleogeography of the Devonian Durazno Group, southern Parana Basin in Uruguay. Journal of South American Earth Sciences, 66, 248-267, https://doi.org/10.1016/j.jsames.2016.01.002.

Van Ranst, G., Pedrosa-Soares, A.C., Novo, T., Vermeesch, P. \& De Grave, J. 2019. New insights from low-temperature thermochronology into the tectonic and geomorphologic evolution of the south-eastern Brazilian highlands and passive margin. Geoscience Frontiers, https://doi.org/10.1016/j.gsf.2019.05.011.

Vermeesch, P. 2009. RadialPlotter: a Java application for fission track, luminescence and other radial plots. Radiation Measurementes, 409410http://www.ucl.ac.uk/ ucfbpve/radialplotter/.

Veroslavsky, G., De Santa Ana, H., Rossello, E. 2004. Depósitos del Jurásico y Cretácico temprano de la región meridional de Uruguay. In: Veroslavsky, G., Ubilla, M., Martínez, S. (Eds.): Cuencas sedimentarias de Uruguay. Mesozoico. Facultad de Ciencias, Montevideo, pp. 117-142.

Wagner, G.A., Gleadow, A.J.W. \& Fitzgerald, P.G. 1989. The significance of the partial annealing zone in apatite fission-track analysis: Projected track length measurements and uplift chronology of the transantarctic mountains. Chemical Geology: Isotope Geoscience section, 79, 295-305, https://doi.org/10.1016/0168-9622(89)90035-3. 
Will, T.M. \& Frimmel, H.E. 2018. Where does a continent prefer to break up? Some lessons from the South Atlantic margins. Gondwana Research, 53, 9-19, https://doi.org/10.1016/j.gr.2017.04.014.

Will, T. , Gaucher, C., Ling, X.X. , Li, X.H. , Li, Q.L., Frimmel, H.E. 2019 Neoproterozoic magmatic and metamorphic events in the Cuchilla Dionisio Terrane, Uruguay, and possible correlations across the South Atlantic. Precambrian Research 320, 303-322.

Wolf, R.A., Farley, K.A. \& Silver, L.T. 1996. Helium diffusion and low-temperature thermochronometry of apatite. Geochimica et Cosmochimica Acta, 60, 4231-4240, https://doi.org/10.1016/S0016-7037(96)00192-5.

Wolf, R.A., Farley, K.A. \& Kass, D.M. 1998. Modeling of the temperature sensitivity of the apatite (U-Th)/He thermochronometer. Chemical Geology, 148, 105-114, https://doi.org/10.1016/S0009-2541(98)00024-2.

Zalán, P. V. 2004. Evolução Fanerozóica das Bacias Sedimentares Brasileiras. In: MantessoNeto, V., Bartorelli, A., Carneiro, C. D. R. \& Neves, B. B. de B. (eds) Geologia Do Continente Sul-Americano: Evolução Da Obra de Fernando Flávio Marques de Almeida. Beca Produções Culturais Ltda, 595-612.

Zambrano, J.J. \& Urien, C.M. 1970. Geological outline of the basins in southern Argentina and their continuation off the Atlantic shore. Journal of Geophysical Research, 75, 1363-1396, https://doi.org/10.1029/JB075i008p01363.

Zerfass, H., Chemale, F., Leandro, C. \& Lavina, E. 2004. Tectonics and sedimentation in Southern South America during Triassic. 166, 265-292, https://doi.org/10.1016/j.sedgeo.2003.12.008. 